\title{
What Does Location Choice Reveal About Knowledge-Seeking Strategies of Emerging Market Multinationals in the EU?
}

\author{
Jindra, Björn ; Hassan, Sohaib S.; Cantner, Uwe
}

\author{
Document Version \\ Accepted author manuscript \\ Published in: \\ International Business Review \\ DOI: \\ 10.1016/j.ibusrev.2014.11.008 \\ Publication date: \\ 2016 \\ License \\ Unspecified
}

Citation for published version (APA):

Jindra, B., Hassan, S. S., \& Cantner, U. (2016). What Does Location Choice Reveal About Knowledge-Seeking Strategies of Emerging Market Multinationals in the EU? International Business Review, 25(1, Part A), $204-220$. https://doi.org/10.1016/j.ibusrev.2014.11.008

Link to publication in CBS Research Portal

\section{General rights}

Copyright and moral rights for the publications made accessible in the public portal are retained by the authors and/or other copyright owners and it is a condition of accessing publications that users recognise and abide by the legal requirements associated with these rights.

\section{Take down policy}

If you believe that this document breaches copyright please contact us (research.lib@cbs.dk) providing details, and we will remove access to the work immediately and investigate your claim. 


\title{
What Does Location Choice Reveal About Knowledge- Seeking Strategies of Emerging Market Multinationals in the EU?
}

\author{
Björn Jindra, Sohaib S. Hassan, and Uwe Cantner \\ Journal article (Post print version)
}

This article was originally published in International Business Review.

First published online: 23 December 2014

DOI: $\underline{10.1016 / j . i b u s r e v .2014 .11 .008}$

Uploaded to Research@CBS: December 2015

Available at Research@CBS

(C) 2015. This manuscript version is made available under the CC-BY-NC-ND 4.0

license http://creativecommons.org/licenses/by-nc-nd/4.0/ 


\title{
What does location choice reveal about knowledge-seeking strategies of
}

\author{
emerging market multinationals in the EU?
}

\author{
Björn Jindra $^{1,2}$, Sohaib S. Hassan ${ }^{3}$ and Uwe Cantner ${ }^{3,4}$ \\ ${ }^{1}$ University of Bremen, Germany; ${ }^{2}$ Copenhagen Business School, Denmark; ${ }^{3}$ Friedrich-Schiller- \\ University, Germany; ${ }^{4}$ University of Southern Denmark, Denmark
}

\begin{abstract}
The European Union is one of the largest recipients of outward foreign direct investment from emerging economies. We apply different discrete choice models to analyze the location choice of 4,555 emerging market firms in 93 sub-national regions of the European Union. In particular, we test to what extent these firms' location choices are related to agglomeration economies and knowledge externalities, because these have been suggested as potential sources to propel learning and technological catching-up. Our results indicate that emerging market firms' location choices are positively affected by agglomeration economies and knowledge externalities. In addition, we can identify differences in the valuation of various subnational location factors as well as differences in the substitution pattern between alternative regions for firms originating from emerging markets. The evidence supports the argument that emerging market firms use outward foreign direct investment to augment ownership specific assets.
\end{abstract}

Keywords: outward FDI, location choice, emerging economies, European Union

Corresponding author: Björn Jindra, bjoern.jindra@uni-bremen.de, Phone: +49(0)421 218666 33, University of Bremen, Institute of Institutional and Innovation Economics, Hochschulring 4, 28359 Bremen, Germany 


\section{Introduction}

The growth of outward foreign direct investment (OFDI) has been phenomenal in the recent era of business globalization. The role of developed-country multinational enterprises (DCMNEs) is generally considered pivotal to this development. Recently, however, emergingeconomy multinational enterprises (EEMNEs) have progressively increased their share in the global OFDI. The global share of OFDI stocks from emerging markets rose from 4 percent in 1980 to around 16 percent in 2010 (UNCTAD, 2011). Among world regions, the European Union (EU) is a prime investment destination for EEMNEs.

A number of authors argued that EEMNEs are fundamentally different from their counterparts in developed countries (Wells, 1983; Lall, 1983; Mathews, 2002; Child and Rodrigues, 2005; Dunning, 2006; Goldstein, 2007; Ramamurti, 2012), and their location strategies are peculiar to their countries of origin (Dunning, 1998; Rugman, 2009). In addition to the traditional location determinants, scholars have argued for the importance of knowledgeseeking OFDI motives for the international ventures of EEMNEs (Makino et al., 2002; Mathews, 2002, 2006; Luo and Tung, 2007; Rugman, 2009). Specifically, it is argued that EEMNEs lack the strength of ownership advantages (e.g., international experience and technological, managerial and marketing competences) traditionally held by DCMNEs (Mathews, 2002; Ramamurti and Singh, 2009). Accordingly, this relative disadvantageous competitive position may prompt EEMNEs to improve their technological and commercial capabilities by following a learning-based knowledge-seeking OFDI strategies aimed at catching up (Mathews, 2006; Rugman, 2009; Li, 2010; Narula, 2012).

A number of studies scrutinize the relevance of EEMNEs' knowledge-driven OFDI strategies examining mainly determinants related to macro-economic environments at the national level of analysis (see among others Makino et al., 2002; Mathews, 2006; Buckley et al., 2007). However, economic geography teaches us that spatially bound agglomeration economies are crucially important in understanding the spatial distribution of firms (Krugman, 1991; Venables, 1996; Fujita et al., 1999). From a theoretical point of view, the technological accumulation approach towards firms' internationalization (Cantwell, 1989, 1995) accommodates these elements. It suggests that ownership advantages are not ex ante characteristics of the foreign parents, but are endogenously created by firms' strategic investments into production and technology in foreign locations, which are characterized by 
spatially bound externalities. Related empirical evidence already established the relevance of agglomeration economies and externalities as crucial factors which explain foreign firms' subnational location pattern in the EU (Cantwell and Piscitello, 2002, 2005; Basile et al., 2008; Mariotti et al., 2010).

If the arguments about knowledge-seeking strategies of EEMNEs in advanced economies hold, we would expect that agglomeration economies and spatially bound knowledge spillover should play a significant role in their location choice too, since they offer sources for local learning and capability formation. Currently, we lack evidence to which extent EEMNEs are attracted by agglomeration economies and knowledge externalities, and whether their subnational location choice differs in that respect from location patterns observed for DCMNEs. Therefore, the main aim of this paper is to generate evidence on these two questions.

We utilize a comprehensive firm-level database pertaining to a total of 32,685 foreign owned affiliates that entered the EU27 ${ }^{1}$ between 1996 and 2010. From this, 4,555 foreign affiliates (14 percent) have direct or indirect ownership by emerging market investors. In line with existing research of foreign firms' location choice (Disdier and Mayer, 2004; Crozet et al., 2004; Basile et al., 2008; Childlow et al., 2009; Fallen and Cook, 2010; Hilbert and Voicu, 2010), we model different sources for agglomeration economies and knowledge externalities including industrial specialization and diversification, urbanization, public science and human resources in science and technology occupations. We also control for other region specific effects such as market size, wage level, infrastructure and geographic distance. Empirically, we employ a utility maximization framework to model location choice in a given set of 93 regions $^{2}$ within the EU using conditional-logit, nested logit and mixed logit estimation techniques.

The remainder of the paper proceeds as follows: In the next section, we set out the theoretical framework and develop our hypotheses about the role of technological and knowledge spillovers for the knowledge-seeking OFDI location choice. In section 3, we provide data information on the extent of OFDI projects in the sub-national regions of the EU. In section 4, we explain our econometric methodology employed to test our main hypotheses. Section 5 shows and explains main results. We discuss our empirical findings and conclude in the final section.

1 In our analysis we use the term EU27 and EU interchangeably. EU27 includes all states have been members of the EU in our period of observation. Therefore, Croatia is not yet considered as an EU states in this analysis.

2 We refer to 'regions' as sub-national rather than supra-national units as in Rugman and Verbeke $(2004,2005)$. 


\section{Literature review and research hypotheses}

\subsection{Theoretical framework}

Early international business theory accentuates the role of firms' ex-ante ownership advantages in exploiting foreign markets, essentially by offsetting the costs of foreign entry at host locations (Caves, 1971; Hymer, 1976; Dunning, 1977). From this perspective, ownership advantages constitute a net cost advantage to foreign owned firms over indigenous firms in the relevant local market. However, this generic definition 'implies a comparison that is neither easy to do, nor appropriate where MNEs are embedded in multiple locations and global markets' (Narula, 2012, p. 190). Firms moving abroad are faced not just with competition from host country firms in the same industry, but also with MNEs of other nationalities located in that market. In addition, the lack of perfect information acts as a constraint in estimating the relative value of firm specific advantages to those of incumbent firms of whatever nationality (ibid.).

The assumption of ex-ante ownership advantages as a precondition for internationalization has been challenged by the technological accumulation approach (Cantwell 1989, 1995). Instead, it suggests that ownership advantages are endogenously created by firms' strategies to invest in multiple locations. This capability based approach links firms' competitiveness to technological accumulation that results from internal economies of scale due to the transfer of innovation within the internal MNE network and external economies associated with the absorption of spatially bound spillover and externalities available at foreign host country locations. Thus, firms may not only exploit but also augment capabilities at foreign host locations (Kuemmerle, 1999; Cantwell and Piscitello, 2005, 2014).

The knowledge-seeking context of the OFDI has been also emphasized in regard to the distinct ownership characteristics of EEMNEs (Dunning, 2006; Ramamurti, 2009; Rugman, 2009; Hennart, 2012). Scholars have argued that EEMNEs are relatively newer in international business, start from relatively earlier levels of value added activities and lack organizational experience (Johansen and Vahlne, 2009; Clarke et al., 2012). It should be noted that this newness is not unique to EEMNEs, since we also find new or 'infant' MNEs originating from developed economies (Narula, 2012). However, it is further suggested that the ownership characteristics of firms are idiosyncratic to their home countries (Dunning, 1998; Ramamurti and Singh, 2009). Such country-specific idiosyncrasies discern the location choices of EEMNEs from their international business peers (Rugman, 2009). 
In contrast to conventional multinational firms, EEMNEs generally arise from highly imperfect markets with lower levels of technological and institutional development, and rely mainly on the home country-specific benefits for the earlier stages of their international activities (Kogut, 1985; Rugman, 2009). Many EEMNEs have developed unique capabilities in low-cost, large-scale production and benefit from cheap input factors, preferential access to local resources and government support. Policies and institutions associated with import substitution have played an important role in the formation of their ownership specific assets (Narula, 2012). For example, closed domestic markets meant that DCMNEs seeking access were obliged to offer access to technologies in exchange. Limited competition led to subsequent underinvestment in technological areas and EEMNEs primarily developed products and innovations best suited to their home markets in the early stages of their internationalization (see among others Zhou et al., 2007; Luo et al., 2011). However, the opportunity to generate rents through pseudo-monopolies created cash rich domestic players from emerging markets that later were able to expand abroad (Narula, 2012).

However, the dependence on home country-specific benefits is only temporarily viable, and firms need to enhance firm-specific ownership assets in order to be globally competitive in new markets (Dunning, 1977). Arguably market reforms in emerging economies have acted as an important push factor for the upgrading of ownership assets, going hand in hand with accelerated internationalization (Cuervo-Cazurra, 2008). For example, increased inward MNE activity led, through linkages and spillovers, to positive effects on the asset portfolio of more competitive emerging market firms. Other domestic firms allied with foreign MNEs to survive in their home markets, while simultaneously upgrading their existing assets to weather the increased competition through greater investment in R\&D (Narula, 2012).

At the same time, the expansion of EEMNEs into foreign markets has been associated with capability building through learning, acquiring or leveraging knowledge resources not available at home locations (Mathews, 2002; Child and Rodrigues, 2005; Luo and Tung, 2007; Lessard and Lucea, 2009; Luo and Rui, 2009; Li, 2010; Kedia et al., 2012). In principal, it is possible to upgrade owner specific assets without the traditional ownership-location advantages in the home country by asset augmentation through internationalization (Narula, 2012). This could be facilitated through internalization of the assets of other firms through mergers and 
acquisitions (M\&As) or internalizing the location assets of foreign locations associated with their knowledge infrastructure and clusters (ibid.).

In both cases, the economic geography of host countries would matter for location choice, since sub-national regions are characterized by intrinsic advantages (or disadvantages) in terms of localized demand and supply factors (Porter, 1990; Krugman, 1991; Fujita et al., 1999). Firms tend to co-locate with similar firms in a cumulative causation process (Markusen and Venables, 1999). Over time, firms' clustering yields agglomeration economies consisting of specialized infrastructure, labor markets and positive externalities characterized by different technological and knowledge spillovers (Glaeser et al., 1992; Krugman, 1991; Venables, 1996). Foreign investors could benefit from location bound spillovers arising from agglomeration economies in at least two ways:

First, foreign investors are faced with uncertainty about new markets (Johanson and Vahlne, 1977; Clarke et al., 2012) and must choose locations that reduce risks associated with OFDI. Agglomeration economies reduce information asymmetry, since the presence of other similar (domestic or foreign) firms within a location signals the existence of relevant supply and demand factors for foreign production, which in turn reduces the risk and uncertainty of new entrants about these foreign locations (Mariotti and Piscitello, 1995; Guimarães et al., 2000; Devereux et al., 2007). This type of information externalities could be particularly relevant to emerging market investors, which lack knowledge about foreign markets to a larger extent than ('mature') DCMNEs due to their early stage in the internationalization process.

Second, agglomeration economies matter for knowledge-seeking type of OFDI, since the geography of $\mathrm{R} \& \mathrm{D}$ and innovation teaches us that knowledge spillovers are spatially bounded (Malecki, 1995, Howells, 1990; Jaffe et al., 1993; Feldman, 1994; Audretsch and Feldman, 1996). As described above, the technological accumulation approach (Cantwell, 1989, 1995) dedicates considerable importance to the presence of knowledge spillovers in foreign locations as an input into the joint learning process of foreign subsidiaries, their suppliers, customers or partners in public sciences present at the locality. These elements proved important factors attracting technological activity of foreign firms into European regions (Cantwell and Iammarino, 2000; Cantwell and Piscitello, 2005), and could also constitute important pull-factors for a knowledge-seeking type of OFDI from EEMNEs in advanced economies. Given their home country-specific development, EEMNEs might seek knowledge spillovers to upgrade their 
ownership specific assets. However, firms' absorptive capabilities (Cohen and Levinthal, 1990), which are a function of their prior R\&D, could constrain EEMNEs' ability to absorb, acquire, and internalize external knowledge in foreign locations, since EEMNEs are often characterized by relatively lower levels of learning capabilities related to their home-country development levels (Hoskission et al., 2000).

An increasing number of empirical studies has examined the effects of agglomeration economies and knowledge externalities on the sub-national location decisions of foreign firms in the EU (Head et al., 1999; Guimarães et al., 2000; Crozet et al., 2004; Barrios et al., 2006; Basile et al., 2008; Devereux et al., 2007; Chidlow et al., 2009; Fallen and Cook, 2010; Hilbert and Voicu, 2010). These studies provide important insights into the sub-national drivers and underlying motives for location choice of inward FDI within European countries. It has also been established that different sources for agglomeration economies and knowledge externalities are not mutually exclusive and thus can affect location choice of foreign firms simultaneously. While some studies also investigate differences in sub-national location choice between European and non-European investors (see for example Crozet et al., 2004 and Basile et al., 2008), existing studies do not address to what extent the sub-national location choice (and underlying investment motives) might differ for foreign investors originating from emerging market economies.

\subsection{Hypotheses}

We now derive a number of specific research hypotheses on the roles of different sources of agglomeration economies and knowledge externalities for EEMNEs' location choice in advanced economies based on the above outlined assumptions: Firstly, EEMNEs differ from 'mature' DCMNEs by the quality of ownership specific assets. Secondly, EEMNEs are likely to implement knowledge-seeking OFDI strategies to upgrade ownership specific advantages through competence creation by taking advantages of foreign market environments. Third, this strategy should be reflected in the relevance of agglomeration economies and location bound externalities in sub-national location choice of EEMNEs within advanced economies. Fourthly, differences in the location pattern between EEMNEs and DCMNEs could be explained by different home country environments, ownership specific assets as well as different levels of absorptive capacity. 
Based on Marshall's (1890) concept of "localization economies", it has been suggested that regional specialization externalities arise from the spatial concentration of firms undertaking the same or related activities within a given region (Arrow, 1962; Romer, 1986; Glaeser et al., 1992; Batista and Swann, 1998). This refers to externalities from firms' access to specialized labor, existing supplier linkages as well as relevant know-how. These industry specific forces generate cumulative mechanisms that enable regions to increase their production, technological and organizational competences over time (Richardson, 1969; Dicken and Llyod, 1990). Specialization patterns exist in sub-national economic systems for production as well as innovation activities, and seem to be stronger in case of the latter (Paci and Usai, 1998). In turn, the technological accumulation approach (Cantwell, 1989; Cantwell, 1995) suggests that foreign firms take advantages of such localized external economies of scale, by locating production as well as innovation activities in specialized localities abroad. Inter-firm networks between foreign MNEs and domestic firms potentially amplify the advantages of spatial concentration in particular lines of technological development, reinforcing the existing pattern of technological specialization of local systems (Cantwell and Iammarino, 1998).

It seems that intra-industry specialization of a region provides MNEs (independent from their origin) the opportunity to access specialized labor, an existing supplier structure as well as knowhow. Under the assumption that EEMNEs internationalize to upgrade ownership advantages by augmenting their production and technological capabilities, they are more likely to choose regions characterized by specialization advantages. In addition, signals from spatial concentration of (foreign and/or domestic firms) within a specific sector could reduce information asymmetry that might be particularly high in case of Greenfield entries by EEMNEs. Since EMNEs also augment their knowledge base through direct acquisition of foreign assets (Child and Rodrigues, 2005; Luo and Tung, 2007; Narula, 2012), they are also more likely to identify suitable companies for takeover or mergers in regions characterized by specialization advantages. Therefore, we propose that:

(H1) Intra-industry spillovers arising from the specialization advantages increase the probability of location choice by foreign investors from emerging markets in the sub-national regions of the EU. 
In addition to specialization advantages or intra-industry spillover, Jacobs (1969) argues that diversity externalities potentially arise from co-location of firms from different industries. Such clustering yields inter-industry spillovers, since firms can access new knowledge, innovative ideas and skills emerging from disparate economic activities (Florida, 1997; Feldman and Audretsch, 1999). Such localized benefits could potentially affect firm growth, since corporate diversification into new product markets facilitates economies of scale and scope (Chandler, 1990). Later this rationale was extended to the diversification of the firm's technological competencies in an international context (e.g., Granstrand and Sjölander, 1992; Granstrand et al., 1997; Cantwell and Piscitello, 2000, 2014; Cantwell, 2009).

Although the creation of large multi-technology corporations through diversification and internationalization has been observed amongst 'mature' DCMNEs since the 1970s, it could be argued that this element is also of importance for 'infant' EEMNEs, since they enter international business today at a stage characterized by high levels of technological interrelatedness and complexity. Under the assumption that EEMNEs seek to diversify into new products and technologies, asset-seeking internationalization could facilitate competence creation by absorbing inter-industry spillover from a diversified industrial structure within the foreign locality. This could foster new interdependent structures of product and technological relatedness between in-house activities of EEMNEs. Thus we posit that:

(H2a) Inter-industry spillovers arising from a diversified industry structure within a subnational region of the EU increase the probability of location choice by foreign investors from emerging markets.

Inter-industry interaction often develops in large urban areas that attract a wide range of economic activities generating also other urbanization economies. It has been argued that industry interaction and urbanization economies develop in so called 'higher order regions', which are especially attractive to large foreign MNEs, since they offer not only dynamism in terms of production and technology within and across sectors, but are also characterized by excellent infrastructure, financial facilities, an attractive business climate and corporate culture as well as general openness to external networks (Cantwell and Iammarino, 1998, 2000). Given that EEMNEs might face higher liability of foreignness compared to DCMNEs over domestic firms (Madhok and Keyhani, 2012), benefits offered to new corporate entrants from emerging 
economies in large urban areas could provide an important reason for initial entry within a foreign host country. Therefore, we posit that:

(H2b) Urbanization economies within a sub-national region of the EU increase the probability of location choice by foreign investors from emerging markets.

The technological accumulation approach towards firms' internationalization holds that firms benefit from external economies that arise from the interactions between local industry and external sources of knowledge at foreign locations (Cantwell, 1989). These external sources for knowledge spillover might include $R \& D$ activity conducted by local customers, suppliers or competitors. Localized knowledge spillovers arise also from science-industry interaction (Jaffe et al., 1993; Nelson, 1993; Nelson and Rosenberg, 1999; Feldman and Audretsch, 1999; Cooke, 2001). In this context, the also the quality of the public research infrastructure proves to be a pivotal in foreign firms' location within foreign countries (Chung and Alcácer, 2002; Cantwell and Piscitello, 2002, 2005). For knowledge-seeking strategies of EEMNEs, knowledge spillovers from localized R\&D activity of external actors within the foreign location should be an important channel for competence augmentation. Therefore, we posit that:

(H3a) Externalities arising from localized $R \& D$ activity increase the probability of location choice by foreign investors from emerging markets in the sub-national regions of the EU.

Given that technology is embodied not only in capital equipment but also in tacit knowhow of a specialized workforce (Cantwell, 1989), the availability of specialized labor in science and technology occupations offers an important channel of knowledge diffusion (Song et al., 2003; Alcácer and Chung, 2007). Thus knowledge-driven internationalization of EEMNEs would be supported by the availability of specialized labor in technological areas relevant to foreign firms' activities abroad. EEMNEs would get direct access to a specialized workforce in the relevant technological area or would benefit from externalities due to labor mobility across firms within a given sector. Therefore, we hypothesize:

(H3b) Externalities arising from specialized labor increase the probability of location choice by foreign investors from emerging markets in the sub-national regions of the EU. 


\section{Data}

We draw upon the firm-level information from the Bureau van Dejk's AMADEUS database (online version 2012). We define a foreign affiliate as a firm that was incorporated between 1996 and 2010 and is located in one of the EU27 countries. The firm has at least one foreign owner that must be located outside the respective EU location country. The possible countries in which the foreign owner is located include EU and non-EU countries (see Annex Table A1 for a complete listing of the countries of origin covered). Foreign ownership is defined as being a direct shareholder (with a minimum of 10 percent equity/or voting rights) or an ultimate owner (with a minimum of 25 percent indirect ownership). After the application of this selection criterion and the elimination of observations with missing information, we arrive at a sample of 32,685 foreign affiliates that have been set up during 1996 and 2010 in the EU27.

About 14 percent of firms $(4,555)$ with foreign ownership in the sample have a foreign owner that originates from the group of emerging economies. From this sub-sample about 65 percent (2,964 firms) have an owner that originates from an emerging economy outside the EU27. The annual entry rates during the observation period increased independently from the origin of investors until the onset of the financial crisis in 2008. The increase was slightly more pronounced since the early 2000s for investors from non-EU emerging economies (see Annex Table A2). In terms of industrial compositions, about 28.5 percent of foreign affiliates are in manufacturing, 70 percent in services and the remainder in other sectors (including agriculture and mining) (see Annex Table A3). There seem to be no major differences in the industrial sector composition of sub-samples depending upon the origin of the foreign owner.

In terms of host country distribution of the foreign affiliates, Great Britain hosted the highest number of foreign affiliates (17.5 percent) of the total population (see Annex Table A4). It is followed by Romania (13.5 percent), Germany (11.8 percent), France (9 percent), Spain (7.4 percent) and Italy (5.4 percent) that also attracted a considerable share of total foreign affiliates in the EU (1996-2010). The exceptionally high share of foreign affiliates based in Romania is at odds with host country inward FDI distributions based on aggregated balance of payment data. The high presence of firms located in Romania can be explained by the above average coverage of AMADEUS data for Romania. To reduce the bias in spatial distribution due to the oversampling in the Romanian sub-sample, we only included foreign affiliates that have at least 20 employees. The host country distribution of the emerging market foreign affiliates follows the 
overall distribution with the exception of slightly higher rates for selected EU12 economies including the Czech Republic, Slovakia, Lithuania, and Latvia as well as Portugal and Malta. This is partially driven by mutual investments among European transition economies (see Annex Table A4).

To allocate foreign affiliates to sub-national regions, we use the EUROSTAT system of regional classification - Nomenclature of Territorial Units of Statistics (NUTS). We adopt the NUTS-1 level breakdown for the 27 EU countries excluding extra-territorial regions. This results in 93 NUTS-1 regions. Selected EU countries implemented territorial reorganization during our observation period (1996-2010). These affected in some cases also the NUTS-1 level for example in Italy or Poland (see Chidlow et al. (2009) for details). Since our research approach requires the application of a unique sub-national classification throughout the whole observation period, we used information from firms' addresses to allocate them a unique NUTS-1 region independent from the year of entry. We applied the official NUTS-1 level nomenclature as of 2010 (Eurostat 2011), which correspond to the final year of our observation period.

It is also important to note that in 12 EU countries (CY, CZ, DK, EE, FI, IE, LT, LU, LV, MTO, SI, SK) the NUTS-0 level (country level) corresponds to the NUTS-1 (sub-national) level. This is mostly the case in countries with relatively small territory and population, where the country level is comparable to 'large socio-economic sub-national regions', which constitute and define NUTS-1 regions in other countries of the EU. In fact, a lower level of regional disaggregation (NUTS-2) could have been more appropriate for the investigation of the role of spatially localized agglomeration economies. In our choice of the NUTS-1 level, we follow other examples of EU wide sub-national location choice analysis (e.g., Basile et al., 2008). Any choice in this context needs to balance comparability of 'regions' and data availability, which is better for the NUTS-1 level in particular when it relates to sector specific information.

The distribution of foreign affiliates in our sample across NUTS-1 level EU regions shows that foreign affiliates are often regionally concentrated in or around the capital cities of the host countries (see Annex Table A5). In the EU15 group ${ }^{3}$, the largest concentration of foreign affiliates was found in the NUTS-1 level regions: Greater London, Ile-de-France and Northwestern Italy. In the new EU member states, the largest numbers of subsidiaries were located in Romanian sub-national regions Macroregiunea trei and Macroregiunea unu as well as

\footnotetext{
${ }^{3}$ EU15 refers to states that became members of the EU until 2003.
} 
in the Polish Region Centralny. From descriptive evidence, we do not find major deviations in the sub-national distribution between DCMNEs and EEMNEs (see Annex Table A5). The latter group seems more frequent in selected regions of transition economies (CZ0, LV0, RO 1-3) and few regions in the EU15 (UKD, UKI, GR3).

\section{Econometric approach}

Following existing approaches in literature (e.g., Devereux and Griffith, 1998; Basile et al., 2008), we assume a simplified decision making process of a firm: First, a firm (investor) makes a decision about serving the foreign market. Second, the firm decides the means of investment. That is, the firm decides whether to serve the foreign market through licensing, alliances, joint ventures or by foreign direct investment as in our case. Then, the firm decides about the potential location for its future activities. We model only the final stage of this process, which is the location choice for OFDI in the EU. Locations are sub-national EU regions (NUTS1 level). We assume that the selection of a particular region by investor depends on the potential profits associated with the host region compared to all other alternatives. The value attached to each location factor affects the profit function. Region level location determinants apply uniformly across all alternatives.

The random utility maximization framework (McFadden, 1974) has been used as a basis for studying discrete choice problems. It assumes that the evaluation of a decision maker among available alternatives can be represented by a utility function. The decision makers choose the alternative from a given set of choices that generates the highest utility. In our analysis, location choice is a discrete choice problem where profit (utility) maximizing firms choose locations from all regions (93 NUTS-1 level sub-national regions) within the EU. We employ the conditionallogit model (CLM) (Carlton, 1979) frequently used in industrial location choice. Coefficients are estimated by maximum likelihood procedures. It enables us to include the location attributes of a relatively large number of alternatives. The CLM approach relies upon the critical assumption that unobserved factors are uncorrelated over alternatives (regions in our case) as well as having the same variance for all alternatives (Train, 2003).

Following Guimarães et al. (2000), we assume the existence of $j$ choices among NUTS-1 regions with $j=1, \ldots ., j$ and $N$ investors with $i=1, \ldots ., N$, then the profit derived by investor $i$ by locating in region $j$ is given by 


$$
\pi_{i j}=\beta^{\prime} z_{i j}+\epsilon_{i j}
$$

where $\beta$ is a vector of unknown parameters, $z_{i j}$ is a vector of observed explanatory variables, and $\epsilon_{i j}$ is a random term. Thus, the profit for the investor $i$ of locating in region $j$ is composed of a deterministic and a stochastic component. The investor will choose the region that will yield him the highest expected profit. If the $\epsilon_{i j}$ is independently and identically distributed (iid), it can be shown that

$$
P_{i j}=\frac{e^{\beta^{\prime} z_{i j}}}{\sum_{j=1}^{J} e^{\beta^{\prime} z_{i j}}}
$$

where $P_{i j}$ is the probability that the investor $i$ locates at region $j$. If we let $d_{i j}=1$ in case investor $i$ chooses choice $j$ and $d_{i j}=0$ otherwise, then we can write the log likelihood of the conditional logit model as

$$
\log L_{c l}=\sum_{i=1}^{N} \sum_{j=1}^{J} d_{i j} \log P_{i j},
$$

In our model, the expected profit ${ }^{4}$ derived by investor $i$, if the investor locates in region $j$, is given by specification:

$$
\begin{gathered}
\text { (I) } \pi_{i j}=\beta_{1} \text { Specialization }_{j h_{i} t_{i_{-1}}}+\beta_{2} \text { Diversification }_{j t_{i_{-1}}}+\beta_{3} \text { Density }+\beta_{4} \text { R\&D }_{j t_{i_{-1}}} \\
+\beta_{5} \text { Technology }_{j h_{i} t_{i_{-1}}}+\beta_{6} \text { Market }_{j t_{i_{-1}}}+\beta_{7} \text { Wage }_{j h_{i} t_{i_{-1}}}+\beta_{8} \text { Labor }_{j t_{i_{-1}}} \\
+\beta_{9} \text { Infrastructure }_{j t_{i_{-1}}}+\beta_{10} \text { Distance }_{j}+\epsilon_{i j}
\end{gathered}
$$

where, $\beta_{1}$ Specialization $_{j h_{i} t_{i-1}}$ is a measure for spillovers arising from the specialization of the industry $h$ of firm $i$ within the region $j$ at time of entry $t_{i_{-1}}$ (in line with $H 1$ ) (see Annex Table A6 for detailed description of all variables). $\beta_{2}$ Diversification $_{j t_{i_{-1}}}$ approximates spillovers arising from the industrial diversification of the region $j$ at time of entry $t_{i_{-1}}$ (in line with $H 2 a$ ), $\beta_{3}$ Density $_{j t_{i-1}}$ is a approximates spillovers arising from urbanization measures in terms of population density of the region $j$ at time of entry $t_{i_{-1}}$ (in line with $H 2 b$ ), $\beta_{4} R \& D_{j t_{i_{-1}}}$ approximates knowledge spillovers arising from $\mathrm{R} \& \mathrm{D}$ expenditures of the region $j$ at time of

\footnotetext{
${ }^{4}$ Please note that in this type of industrial location choice model the expected profit is equated with the utility derived by investor $i$, if the investor locates in region $\mathrm{j}$. It is a latent variable that is not related to the actual 'profit' derived by the firm.
} 
entry $t_{i_{-1}}$ (in line with $\mathrm{H} 3 \mathrm{a}$ ) and $\beta_{5}$ Technology $_{j t_{i_{-1}}}$ as a proxy for externalities from human capital embodied technology measured as the share of human resources in science and technology occupations in total employment of industry $h$ of firm $i$ within the region $j$ at time of entry $t_{i_{-1}}$ (in line with $H 3 b$ ).

In addition, we include $\beta_{6}$ MarketSize $_{j t_{i-1}}$ as a proxy for the regional demand measured by GDP of the region $j$ at time of entry $t_{i_{-1}}, \beta_{7} W a g e_{j h_{i} t_{i_{-1}}}$ as a proxy for the labor cost measured in hourly compensation in industry $h$ of firm $i$ within the region $j$ at time of entry $t_{i_{-1}}$, $\beta_{8}$ Labor $_{j t_{i-1}}$ as a proxy for the labor supply measured by the share of tertiary students within region $j$ at time of entry $t_{i_{-1}}, \beta_{9}$ Infrastructure $_{j t_{i_{-1}}}$ as a proxy of the quality of infrastructure measured by the density of roads within region $j$ at time of entry $t_{i_{-1}}$. Finally, we insert $\beta_{10}$ Distance $_{j}$ as a measure of the geographical distance between the capital city of the country $j$ of the region and the capital city of the country of investor of firm $i ; \epsilon_{i j}$ is a random error term. Apart from Distance, all explanatory variables are measured at $t_{-1}$ as the year preceding the entry of the investor $i$. By lagging the respective explanatory variables by one year before entry, we reduce possible endogeneity between the investment of firms and the region specific endowment factors.

In order to control for correlation in the error term through unobserved national level location factors, we include into the above presented equation (1) dummies for sub-national regions that belong to the same country. In case the NUTS-1 region equals the NUTS-0 (country) level, we group the respective region into a group of similar countries. As a result we obtain a list of 12 host country groups: Austria, France, Germany, Italy as separate country dummies; the group of the United Kingdom and Ireland; the Benelux group (Belgium, Netherlands, and Luxembourg), the group of Scandinavian EU countries (Denmark, Sweden, and Finland); the South European group (Spain, Portugal, Greece); the Baltic group (Estonia, Lithuania, Latvia); the Central European EU accession countries from 2004 (Czech Republic, Slovakia, Slovenia, Hungary, Poland); the remaining two EU accession countries from 2004 (Cyprus and Malta); and the East European EU accession countries from 2007 (Romania and Bulgaria). 
To measure the effect on location choice that is related to the origin of the investor, we include a vector $\gamma^{\prime}$ Originrdum $_{i}$ that constitutes interaction effects between a dummy of the investor group of firm $i$ and the exogenous variables into our base line model:

$$
\text { (II) } \pi_{i j}=\beta^{\prime} z_{i j}+\gamma^{\prime} \text { Originrdum }_{i} * v_{i j}+u_{i j},
$$

We differentiate investors from developed countries (DCMNEs) and investors from emerging economies (EEMNEs). Within the group of EEMNEs, we further isolate investors that originate from the EU12 (EU-EEMNEs) and investors that came from emerging economies outside the EU27 (Non-EU-EEMNEs) (see Annex Table A1 for country lists per group). This way we can test for differences in parameters $\beta_{1}$ to $\beta_{10}$ for firms from a specific investor group (e.g., EEMNEs) and the parameter estimates $\beta_{1}$ to $\beta_{10}$ for the respective reference group (e.g., DCMNEs). We select this identification strategy, since it offers test statistics on significant differences in parameter estimates depending on the investor group of foreign affiliates that would not be available when we would estimate the parameters in separate sub-samples. Thus, selected identification approach includes a control group which serves as reference for the estimation results obtained.

\section{Estimation results}

The individual variance inflation factors for our independent variables are between 1.04 and 2.63 and the average variance inflation factor stands at 1.61 and thus well below the threshold of 6 (see Annex Table A7). Therefore, we assume that collinearity between independent variables is at acceptable levels. Moreover, the result of the Pearson correlation tests between all independent variables indicates fairly low correlation values for most variables (see Annex Table A7). The highest correlation values exist between GDP, R\&D and wages but these are below correlation values of 0.7 . In sum, collinearity and correlation statistics indicate that multicollinearity is not a major concern in our estimations.

\subsection{Base line scenario for location choice}

The first estimation seeks to assess the effects of agglomeration-related spillovers, while controlling for other conventional location determinants on the location choice of all foreign affiliates in the sample regardless of their nationalities, i.e., this corresponds to the base line model (without any country of origin effects) (see first column Table 1). 
Table 1 CLM regression results

\begin{tabular}{|c|c|c|c|c|c|c|c|c|}
\hline \multirow{2}{*}{$\begin{array}{c}\text { VARIABLES } \\
\text { Specialization }\end{array}$} & \multicolumn{2}{|c|}{ (1) Base Model } & \multicolumn{2}{|c|}{ (2) EEMNE } & \multicolumn{2}{|c|}{$\begin{array}{c}\text { Interaction models }^{1} \\
\text { (3) EU-EEMNE }\end{array}$} & \multicolumn{2}{|c|}{ (4) Non-EU-EEMNE } \\
\hline & $0.715 * * *$ & $(0.0128)$ & $0.729 * * *$ & $(0.0139)$ & $0.727 * * *$ & $(0.0139)$ & $0.731 * * *$ & $(0.0139)$ \\
\hline Diversification & $0.317 * * *$ & $(0.0452)$ & $0.425 * * *$ & $(0.0473)$ & $0.424 * * *$ & $(0.0480)$ & $0.446 * * *$ & $(0.0473)$ \\
\hline Density & $0.222 * * *$ & $(0.0103)$ & $0.189 * * *$ & $(0.0106)$ & $0.206 * * *$ & $(0.0109)$ & $0.184 * * *$ & $(0.0107)$ \\
\hline$R \& D$ & $0.133 * * *$ & $(0.0135)$ & $0.109 * * *$ & $(0.0144)$ & $0.112 * * *$ & $(0.0147)$ & $0.108 * * *$ & $(0.0145)$ \\
\hline Technology & $0.172 * * *$ & $(0.0178)$ & $0.134 * * *$ & $(0.0192)$ & $0.119 * * *$ & $(0.0192)$ & $0.134 * * *$ & $(0.0193)$ \\
\hline Market & $1.080 * * *$ & $(0.0125)$ & $1.083 * * *$ & $(0.0129)$ & $1.075 * * *$ & $(0.0132)$ & $1.073 * * *$ & $(0.0131)$ \\
\hline Wage & $-0.141 * * *$ & $(0.0212)$ & $-0.0724 * * *$ & $(0.0216)$ & $-0.102 * * *$ & $(0.0225)$ & $-0.083 * * *$ & $(0.0222)$ \\
\hline Labor & $0.083 * *$ & $(0.0259)$ & $0.108 * * *$ & $(0.0276)$ & $0.0595 * *$ & $(0.0281)$ & $0.117 * * *$ & $(0.0277)$ \\
\hline Infrastructure & $-0.086 * * *$ & $(0.0153)$ & $-0.116^{* * *}$ & $(0.0156)$ & $-0.101 * * *$ & $(0.0160)$ & $-0.104 * * *$ & $(0.0159)$ \\
\hline Distance & $-0.989 * * *$ & $(0.0118)$ & $-0.889 * * *$ & $(0.0134)$ & $-0.884 * * *$ & $(0.0134)$ & $-0.891 * * *$ & $(0.0135)$ \\
\hline \multicolumn{9}{|c|}{ Interaction terms - country of origin $^{1}$} \\
\hline Specialization & - & - & $-0.110 * *$ & $(0.0355)$ & $-0.261 * * *$ & $(0.0613)$ & -0.0420 & $(0.0428)$ \\
\hline Diversification & - & - & $-0.788 * * *$ & $(0.113)$ & $-0.994 * * *$ & $(0.185)$ & $-0.928 * * *$ & $(0.142)$ \\
\hline Density & - & - & $0.305^{* * *}$ & $(0.0239)$ & $0.217 * * *$ & $(0.0449)$ & $0.325^{* * *}$ & $(0.0287)$ \\
\hline$R \& D$ & - & - & $0.191 * * *$ & $(0.0319)$ & -0.0845 & $(0.0519)$ & $0.313 * * *$ & $(0.0393)$ \\
\hline Technology & - & - & $0.181 * * *$ & $(0.0484)$ & $0.297 * * *$ & $(0.0892)$ & $0.131 * *$ & $(0.0561)$ \\
\hline Market & - & - & 0.0272 & $(0.0301)$ & $-0.164 * *$ & $(0.0604)$ & $0.118 * * *$ & $(0.0352)$ \\
\hline Wage & - & - & $-0.432 * * *$ & $(0.0359)$ & $-0.502 * * *$ & $(0.0676)$ & $-0.323 * * *$ & $(0.0431)$ \\
\hline Labor & - & - & $-0.506^{* * *}$ & $(0.0594)$ & $0.458 * * *$ & $(0.110)$ & $-0.793 * * *$ & $(0.0722)$ \\
\hline Infrastructure & - & - & $0.274 * * *$ & $(0.0224)$ & $0.248 * * *$ & $(0.0415)$ & $0.264 * * *$ & $(0.0270)$ \\
\hline Distance & - & - & $-1.086^{* * *}$ & $(0.0371)$ & $-0.840 * * *$ & $(0.0453)$ & $-1.321 * * *$ & $(0.0695)$ \\
\hline \multicolumn{9}{|c|}{ Host country dummies $^{2}$} \\
\hline cd1 & $1.225 * * *$ & $(0.0517)$ & $1.152 * * *$ & $(0.0530)$ & $1.215^{* * *}$ & $(0.0539)$ & $1.227 * * *$ & $(0.0525)$ \\
\hline $\mathrm{cd} 2$ & $0.482 * * *$ & $(0.0510)$ & $0.535 * * *$ & $(0.0506)$ & $0.466 * * *$ & $(0.0529)$ & $0.494 * * *$ & $(0.0516)$ \\
\hline $\mathrm{cd} 3$ & $4.464 * * *$ & $(0.0636)$ & $4.425 * * *$ & $(0.0636)$ & $4.303 * * *$ & $(0.0675)$ & $4.379 * * *$ & $(0.0657)$ \\
\hline $\operatorname{cd} 4$ & $1.594 * * *$ & $(0.178)$ & $1.202 * * *$ & $(0.187)$ & $1.468 * * *$ & $(0.197)$ & $1.111^{* * * *}$ & $(0.204)$ \\
\hline $\operatorname{cd} 5$ & $1.946 * * *$ & $(0.0498)$ & $1.968 * * *$ & $(0.0498)$ & $1.923 * * *$ & $(0.0522)$ & $1.920 * * *$ & $(0.0509)$ \\
\hline $\operatorname{cd} 6$ & $-0.171 * * *$ & $(0.0357)$ & $-0.153 * * *$ & $(0.0358)$ & $-0.189 * * *$ & $(0.0372)$ & $-0.177 * * *$ & $(0.0362)$ \\
\hline $\mathrm{cd} 7$ & $1.003 * * *$ & $(0.0427)$ & $0.988 * * *$ & $(0.0427)$ & $1.024 * * *$ & $(0.0440)$ & $0.977 * * *$ & $(0.0431)$ \\
\hline $\operatorname{cd} 8$ & $4.027 * * *$ & $(0.0659)$ & $4.044 * * *$ & $(0.0657)$ & $3.955^{* * *}$ & $(0.0689)$ & $3.864 * * *$ & $(0.0682)$ \\
\hline cd9 & $1.316 * * *$ & $(0.0328)$ & $1.301 * * *$ & $(0.0329)$ & $1.292 * * *$ & $(0.0339)$ & $1.268 * * *$ & $(0.0334)$ \\
\hline $\operatorname{cd} 10$ & $0.162 * * *$ & $(0.0424)$ & $0.183 * * *$ & $(0.0423)$ & $0.155 * * *$ & $(0.0438)$ & $0.145 * * *$ & $(0.0430)$ \\
\hline $\operatorname{cd} 11$ & $0.948 * * *$ & $(0.0427)$ & $0.952 * * *$ & $(0.0425)$ & $0.838 * * *$ & $(0.0447)$ & $0.912 * * *$ & $(0.0434)$ \\
\hline Observations & $2,901,307$ & & $2,901,307$ & & $2,625,742$ & & $2,753,955$ & \\
\hline Log-likelihood & -128562 & & -127822 & & -116757 & & -122558 & \\
\hline Chi-square & 30462 & & 32067 & & 28046 & & 28562 & \\
\hline P-value Chi & 0.00000 & & 0.00000 & & 0.00000 & & 0.00000 & \\
\hline PseudoR2 & 0.123 & & 0.128 & & 0.123 & & 0.120 & \\
\hline
\end{tabular}

Note: ${ }^{1}$ Interaction of variables with dummy for investors from all emerging markets (specification (2)), from European emerging markets (specification (3)), and non-EU emerging market (specification (4)) (see Annex Tables A1 for country lists). ${ }^{2}$ Ghost country groups: cd1(AT), cd2(BE, NL, LU), cd3(RO, BG), cd4(CY, MT), cd5(CZ, SK, SI, HU, PL), cd6(DE), cd7(DK, SE, FI), cd8(EE, LT, LV), cd9(ES, PT, GR), cd10(FR), cd(11(IE, UK), cd12(IT) (reference group).

Robust standard errors in parentheses $* * * \mathrm{p}<0.001, * * \mathrm{p}<0.05, * \mathrm{p}<0.1$ 
We find a significant and positive effect of industry specialization ('Specialization'), i.e. the foreign entry is more likely, when the industry in which the affiliate invests is characterized by specialization advantages within the respective region in comparison to all other alternative regions.

In turn we find a positive and significant coefficient of the diversification measure ('Diversification'). However, since it is operationalized by the Herfindhal-Index (see Annex Table A6), a higher value indicates a less diversified industrial structure within the respective region. Thus, the location probability is higher for regions with a less diversified, i.e., specialized industrial structure in comparison to all other alternatives.

We also find a positive and significant coefficient for our urbanization proxy ('Density'), i.e. regions with higher population density are more likely to attract foreign affiliates. In line with our expectation, we find a positive and significant coefficient for $\mathrm{R} \& \mathrm{D}$ intensity (' $R \& D$ '). This suggests that regions with higher $R \& D$ intensity are more likely to attract foreign affiliates. Finally, we find a positive and significant coefficient for human resources in science and technology occupations within the region ('Technology'). Thus, regions characterized by a relatively high endowment of human resources in science and technology occupations in the investing industry in comparison to alternatives, are more likely to attract entry by foreign affiliates.

Concerning our control variables for other key location factors in the base line scenario (without country of origin effects), we find significantly positive effects of regional market size ('Market') and the supply of labor ('Labor'). In contrast, we find a significantly negative effect of the level of wage in the investing sector ('Wage'), i.e. controlling for human capital we find that the wage level lowers the location probability of foreign affiliates across EU regions. In turn, we also find a significantly negative effect of the distance between the home country and the target region ('Distance'). This implies that the closer the home country of the foreign investor, the higher the likelihood of entry decision. Not in line with general intuition, we find a negative and significant effect of the quality of transport infrastructure ('Infrastructure') on the location probability, which would suggest that regions with a higher road density are less likely to attract foreign affiliates. Apart from the infrastructure, indicator the effects of our control variables are 
found largely consistent with existing studies on sub-national location choice in the European context (e.g., Head et al., 1999; Crozet et al., 2004; Devereux et al., 2007; Basile et al., 2008).

\subsection{Country of origin effects on location choice}

Now we turn to the interpretation of statistically significant differences in parameter estimates between investors depending on the country of origin (see column (2) to (4) in Table 1). Thereby, the group of foreign affiliates that originates from the EU15 and non-European developed markets (see Table A1 for detailed country list) serves as a reference group (DCMNEs) in our subsequent estimations. It is important to note that the coefficients of the country of origin effects have to be interpreted in reference to the control group to evaluate their effect.

First, we investigate differences between the EEMNEs and DCMNEs (see column (2) in Table 1). The estimation results show that the coefficient for the interaction term of EEMNEs and 'Specialization' is negative (-0.110) and significant. If we add this effect to the corresponding coefficient for 'Specialization' (0.729) in the reference group (DCMNEs), the overall effect for foreign affiliates is still positive (0.729 - 0.110). This implies that the foreign entry by firms from emerging market economies is more likely when the industry in which the affiliate invests is characterized by specialization advantages within the respective region in comparison to all other alternative regions. However, the positive effect of industry specialization on location probability is significantly lower for EEMNEs compared to DCMNEs. As our further estimation results show, this significant difference applies mainly to emerging market investors that originate from the EU12 (see corresponding coefficients in column (3) in Table 1), since emerging market investors from outside the EU27 do not significantly differ in their positive valuation of industry specialization advantages in EU regions from DCMNEs (see corresponding coefficients in column (3) in Table 1).

We obtain a different outcome when we consider significant differences between EEMNEs and DCMNEs in their valuation of industry diversification of regions. The estimation results show that the coefficient for the interaction term of EEMNEs and 'Diversification' is negative (-0.778) and significant (see column (2) in Table 1). If we add this effect to the corresponding coefficient for 'Diversification' in the control group (0.425), the overall effect for foreign affiliates turns negative $(0.425$ - 0.778). Given the inverse operationalization of 
'Diversification', this implies that the foreign entry by firms from emerging market economies is more likely when the region is characterized by a diversified industry structure in comparison to all other alternative regions. It is important to note that this result is not at odds with our finding for the effect of industry specialization advantages for EEMNEs described above, since the latter is industry and region specific, and diversification is only region specific. Thus, an industry specialization within the region and a more diversified industrial structure compared to other regions can be found within the same region.

If we now investigate the role of urbanization economies, we find that the coefficient for the interaction term of EEMNEs and 'Density' is positive (0.305) and significant. If we add this effect to the corresponding coefficient for 'Density' (0.189) in the reference group (DCMNEs), the overall effect for foreign affiliates is positive $(0.189+0.305)$. This implies that the foreign entry by firms from emerging market economies is more likely in the regions that are characterized by high population density in comparison to alternative regions. This significant difference applies to European and non-European emerging market investors equally (see column (3) and (4) in Table 1).

The estimations results from the conditional logit estimation framework also indicate significant differences with regard to the role of externalities arising from localized R\&D activity (' $R \& D$ ') as well as specialized technology related labor ('Technology'). Following the above described interpretation procedure; we find that EEMNEs seems to be significantly more responsive to regional $R \& D$ intensity ('R\&D') (see column (2) in Table 1). The effect seems to be largely driven by emerging markets investors from non-EU countries (see column (4) in Table 1), since the effect of the intensity of regional $R \& D$ expenditures for European emerging markets investors is not significantly different from DCMNEs (see column (3) in Table 1). In turn, we find that EEMNEs value the availability of labor in science and technology occupations within the industry of the region significantly higher that DCMNEs as reference group. This effect seems to apply to both European and non-European emerging market investors (see column (2) to (4) in Table 1).

Let us now take a look at any significant differences between EEMNEs and DCMNEs in their valuation of other key location factors apart from externalities (see column (2) to (4) in Table 1). We find that EEMNEs do not seem to significantly differ from DCMNEs in their positive evaluation of the sub-national market size ('Market'). However, this might be explained 
by an opposing sign of the coefficient of the respective interaction term depending on the origin of emerging market investors: European EEMNEs attribute significantly less weight, whereas emerging economy investors from outside the EU attribute significantly more weight to the subnational market size. Our results also indicate that European and non-European EEMNEs are more sensitive to sector-specific wages ('Wage'), i.e., the wage level within the sector of investment lowers the location probability more than in case of DCMNEs. Overall, EEMNEs seem to attribute significantly less importance to the supply of tertiary students in the region ('Labor'). This result seems to be driven by non-European emerging market investors, since the overall effect is positive for the EU-based emerging market investors. The effect of regional infrastructure ('Infrastructure') is positive for both, European and non-European, EEMNEs. Finally, we find that both European and non-European EEMNEs are less likely to locate if they originate from more distant home countries compared to DCMNEs ('Distance').

\subsection{Robustness checks}

\section{Relaxing the IIA assumption}

The results obtained from the conditional logit estimation hold under the so called IIA assumption that the error terms are independently and identically distributed across alternatives. This implies that for any two alternatives in the set of alternatives, the ratio of probabilities is independent of the attributes or existence of all other alternatives, i.e., in our context, all regions are equal substitutes. Generalized Extreme Value (GEV) models allow for a variety of substitution patterns among the alternatives. A widely used GEV application is the nested logit model. According to Train (2003), a nested logit model is appropriate when the choice set available to a decision maker can be partitioned into subsets, known as nests, in such a way that the IIA holds within each nest but does not hold in general for alternatives in different nests. In other words, this approach is appropriate when there is a correlation for unobserved reasons between the alternatives in each nest but no correlation between alternatives in different nests. When all the correlations are 0 , the GEV model becomes the product of independent extreme value distributions, which correspond to a standard logit model.

Therefore, we estimate a random utility maximum likelihood (RUM) consistent nested logit model (see Heiss, 2002) based on our specification used in the base model and nests that 
correspond to the countries/country groups, which we defined as host country dummies in the conditional logit approach. The estimation results show that the sign of the coefficients of the base model do not differ from the coefficients obtained by the conditional logit approach except for the effect of infrastructure (see Annex Table A8). The log-sum coefficients or dissimilarity parameters (/cd_tau) reflect the degree of independence among the unobserved portions of utility for the alternatives in each of our nests. A higher value means greater independence and less correlation, i.e. the alternatives in the nest are dissimilar (for unobserved reasons). The result of the LR test would indicate that we reject the null hypothesis that all of the log-sum coefficients are $1(\mathrm{p}=0.0000)$ and hence we should use a nested rather than a standard logit. However, our model is not RUM consistent since all dissimilarity parameters must be between 0 and 1 , which is not the case for (Austria, Benelux, and Scandinavia). This can lead to misspecification (Heiss, 2002).

An alternative approach is the mixed logit model that avoids the three limitations of logit models by allowing for random taste variation, unrestricted substitution patterns, and correlation in unobserved factors over time. Mixed logit models are based on the functional form chosen for the choice probabilities. Mixed logit probabilities are the integrals of standard logit probabilities over a density of parameters. When estimating mixed logit models, we estimate two sets of parameters: First, the parameters that also enter the logit formula; these parameters have a density; and second the set of parameters that describes this density. McFadden and Train (2000) have shown that the mixed logit is highly flexible and can approximate any random utility model.

Basile et al. (2008) exploited the flexibility of mixed logit models to estimate the subnational location determinants of foreign firms in the EU15 during the 1990s. Thereby they implemented estimations on separate sub-samples depending on the origin of the investor. We follow this approach and run mixed logit estimations using the location determinants and dummies for host countries/country groups that also entered our conditional logit model estimations. We run mixed logit estimations on the full sample, the sub-sample of all EEMNEs, the sub-sample of European EEMNEs and non-European-EEMNEs (see Annex Table A9). Looking first at the substitution pattern in the full sample, we find, in line with Basile et al. (2008), significant standard deviations for urbanization economies ('Density') and distance to the home country of the foreign investor ('Distance'). In addition, we find significant standard 
deviations for regional diversification ('Diversification') and the supply of tertiary students ('Labor'). This suggests that if a region in the EU27 becomes less attractive (due to a change in some of its observable or unobservable attributes), foreign firms seem more likely to choose other regions sharing similar industrial structure, population density, supply of graduates and at similar distance to home countries. The result of the estimated mean of the parameter associated with the specified location factors (see column (1) Table A9) do not differ in terms of the sign nor much in terms of magnitude compared to the results obtained for the corresponding logit estimation (column (1) Table 1).

Our results show that the LR-test on the standard deviations is not significant in case of the mixed logit estimated in the sub-sample includes all EEMNEs. It is statistically significant for European sub-sample ( $p>0.001)$ and non-European $(p>0.005)$. In both cases we find significant standard deviations for regional diversification ('Diversification') and the supply of tertiary students ('Labor') (see column (3) and (4) in Table A9). This implies that if a region in the EU27 becomes less attractive, foreign firms from emerging markets seem more likely to choose other regions sharing similar industrial structure and supply of graduates. In case of the EU-based emerging market investors this applies also to the similarity of EU regions in the supply of human resources in science and technology occupations (see column (3) in table A9). The result of the estimated mean of the parameter associated with the specified location factors for the subsamples of European and non-European emerging market investors (see column (3) and (4) in Table A9) are identical in terms of significance and sign of the overall effects compared to the interaction terms in the conditional logit estimation (see column (3) and (4) in Table 1). The only exception to this is the results for the infrastructure variable ('Infrastructure'), which is not significant in case of the mixed logit.

In sum, we conclude that the parameter estimates results obtained for the mean of location factors obtained in the conditional logit approach seem to hold in terms of significance and sign of the coefficients, when we relax the restrictive IIA assumption using the mixed logit. This applies also for differences in parameter estimates depending on the investor group of origin. The mixed logit revealed that the substitution patterns between regions depend not on a single characteristic but on a combination of location factors that also differ depending upon the origin of the investor. 


\section{Controlling for sector and firm specific effects}

So far we have used the full set of firms for conditional logit estimations disregarding sector specificity. Thus home country effects could be influenced by sector heterogeneity. Therefore, we include into our base line model interaction terms for each of the location factors and a dummy that equals one in case the foreign affiliate belongs to the manufacturing sector, and zero if it belongs to the service sector. ${ }^{5}$ In addition, we include two more sets of interaction terms: The first set captures the effects related to the mode of entry, which has been documented to influence the relevance of location factors in sub-national choice by foreign investors (see for example Basile, 2004). We create a dummy variable that equals one in case the foreign affiliate was set up as an M\&A, and zero in case of Greenfield investments. Second, we control for the fact whether the foreign investor had any prior experience in the respective host country. Therefore, we create a dummy that equals one in case the foreign investor had other foreign affiliates within the respective host country prior to setting up the foreign affiliate in question; and zero otherwise.

Adding these additional three sets of interaction terms, we subsequently re-estimate our specifications using the conditional logit approach. The corresponding results (see Annex column (1) Table A10) for the base model confirm the sign and significance of the parameter estimates of the mean for all location factors obtained in our prior conditional logit estimation (see column (1) Table 1). The same applied to the significant differences of location factors between EEMNEs and DCMNEs. The only exception to this is that we can no more find significant differences in the valuation of industry specialization advantages ('Specialization') (see Annex column (2) Table A10). We can also confirm the significant differences of location factors between European EEMNEs and DCMNEs apart from the fact that we do not find any more that a higher valuation is associated with the regional supply of tertiary students ('Labor') by European EEMNEs (see Annex column (3) Table A10). Controlling for sector and firm specific effects also renders prior significantly higher valuation of externalities related to $R \& D$ expenditures (' $R \& D$ ') and human resources in science and technology occupations ('Technology') by non-European EEMNEs insignificant (see Annex column (4) Table A10). However, both effects are still overall positive effect on their location probability. This applies

\footnotetext{
${ }^{5}$ Please note that this dummy variable omits 1.46 percent of the firms in the full sample which belong to other sectors (e.g., agriculture and mining).
} 
also to the supply of tertiary students ('Labor') and in a negative sense for the impact of the sector specific wage level ('Wage').

\section{Controlling for sample bias}

Finally, we account for a potential estimation bias in our parameter estimates due to the oversampling of foreign affiliates located in Romania in our dataset as described above. Therefore, we repeat the conditional logit estimation using the specification that controls for sector and firm specific effect and host country/country group effects excluding the Romanian sub-sample. Although the results ${ }^{6}$ for the coefficients in the reference group (DCMNEs) are consistent with our prior estimations in the full sample, this does not apply to all identified statistical differences according to country of origin (displayed in Table 1 above).

For the EEMNEs, we cannot detect any more statistical differences in the valuation of specialization economies between developed and emerging economies. Industrial specialization advantages ('Specialization') still exert an overall positive effect on location probability of EEMNEs. This picture applies to emerging market investors from the EU and from outside the EU. The results indicate that externalities related to a diversified industrial structure of the region ('Diversification') have a negative effect on the location of all EEMNEs; the effect is statistically less significant but still negative for non-EU EEMNEs. Furthermore, we find positive effects of urbanization economies ('Density') on the location probability of EEMNEs that is statistically higher compared to DCMNEs. This applies equally to EU-EEMNEs and non-EU EEMNEs. Externalities from localized $\mathrm{R} \& \mathrm{D}$ (' $R \& D$ ') are also confirmed to exert a positive effect on the location probability of all EEMNEs, but the effect is not anymore statistically different from DCMNEs. In turn, externalities from a high share of human resources in science and technology in the respective industry and region ('Technology') increase the location probability of all EEMNEs, and the corresponding effect is statistically higher in case of EU-EEMNEs in comparison to DCMNEs.

The effects for all other location factors are confirmed. Here corresponding statistical differences for EU-EEMNEs in comparison to DCMNEs are also confirmed. In case of non-EU EEMNEs we find no more statistically different effects in comparison to DCMNEs for regional market size ('Market') and the sector specific wages ('Wages'). The statistically significantly

\footnotetext{
${ }^{6}$ Results are available upon request from authors.
} 
different effects of the supply of tertiary students ('Labor'), transport infrastructure ('Infrastructure') and geographic distance ('Distance') obtained in our earlier conditional logit estimation are robust to the exclusion of the Romanian sub-sample.

\section{Discussion}

Overall our estimation results confirm that agglomeration economies matter for the subnational location choice of foreign investors in the EU (e.g., Mariotti and Piscitello, 1995; Barrios et al., 2006; Devereux et al., 2007; Basile et al., 2008; Chidlow et al., 2009; Mariotti et al., 2010; Fallen and Cook, 2010; Hilbert and Voicu, 2010), when controlling for other market and efficiency related drivers of foreign firms' location choice. We find that this relationship applies also to emerging market investors. Given that the access to spatially bounded external economies at foreign locations has been theoretically linked to a process of technological accumulation and firm growth (Cantwell, 1989, 1995), our findings suggest the argument that emerging market firms augment ownership specific assets through outward FDI into advanced economies. This is in line with existing evidence that indicated the relevance of knowledgeseeking OFDI strategies for EEMNEs (Makino et al., 2002; Luo and Tung, 2007).

Our analysis shows that emerging market firms value externalities from location bound specialization positively. Thus, we cannot reject hypothesis (1) that intra-industry spillovers arising from the industry specialization increase the probability of location choice by foreign investors from emerging markets. However, further investigation shows that the positive effect of industry specialization on location probability is significantly lower for EEMNEs compared to DCMNEs, which is largely driven by emerging market investors that originate from the EU12. This effect could be explained by signals that reduce information asymmetries of about the foreign location (see e.g., Mariotti and Piscitello, 1995) as well as specialization advantages related to a specialized workforce, linkages to supplier or the presence of industry-specific know how (Cantwell and Immarino, 2000; Barrios et al., 2006; Basile et al., 2008).

We obtain opposing effects between EEMNEs and DCMNEs in their valuations of diversification externalities of EU regions. Foreign entry by firms from emerging market economies is more likely, when a given region is characterized by a diversified industry structure in comparison to all other alternative regions. The opposite is the case for DCMNEs. The latter finding seems not in line with existing evidence of the role of diversity externalities in foreign 
firms' location choice within EU countries (Barrios et al., 2006; Devereux et al., 2007). This could potentially be explained by different measures used to proxy diversification economies. However, in the context of our analysis we cannot reject hypothesis $(2 a)$ that inter-industry spillovers increase the probability of location choice by foreign investors from emerging markets. This location choice pattern potentially reveals that EEMNEs seek to diversify into new products and technologies, and use asset-seeking internationalization to facilitate competence creation by absorbing inter-industry spillover from a diversified industrial structure within the foreign locality. This would correspond to observations made on the link between corporate technological diversification and internationalization of DCMNEs at an earlier stage of their development (e.g., Granstrand and Sjölander, 1992; Granstrand et al., 1997; Cantwell and Piscitello, 2000).

We also find that foreign entry by firms from emerging market economies is more likely in the regions that are characterized by high population density in comparison to alternative regions. The effect is stronger in case of EEMNEs vs. DCMNEs. Thus, we cannot reject hypothesis $(2 b)$ that urbanization economies increase the probability of location choice by foreign investors from emerging markets. It seems that EEMNEs favor in particular 'higher order regions' that do not only offer spillovers within and across industries, but are characterized by excellent infrastructure, financial facilities, attractive business climate and corporate culture as well as general openness to external networks (Cantwell and Iammarino, 1998; 2000). This finding could also be related to the fact that EEMNEs confront higher levels of liability of foreignness compared to DCMNEs (Madhok and Keyhani, 2012) and therefore prefer benefits from entry in large urban areas.

The estimation results also indicate significant differences between EEMNEs and DCMNEs with regard to the role of externalities arising from localized R\&D expenditure and specialized labor. We find that EEMNEs seem to be significantly more responsive to regional $R \& D$ intensity, which seems to be largely driven by emerging markets investors from non-EU countries. Thus, we cannot reject hypothesis $(3 a)$ that externalities arising from localized R\&D activity increase the probability of location choice by foreign investors from emerging markets in the sub-national regions of the EU. In addition, we find that EEMNEs value the availability of labor in science and technology occupations within the industry of the region significantly higher than DCMNEs. This effect seems to apply to both the EU and the non-EU emerging market 
investors. Therefore, we can also not reject hypothesis $(3 b)$ that the availability of human resources in science and technology occupations in the target industry of the region increases the location probability of emerging market firms.

To put these results into perspective, all these findings seem to be in line with prior results for the EU that indicated a positive effect of localized R\&D activity on the location choice of foreign firms. This applies to the general location choice (see for example Basile et al., 2008) as well as the location of foreign technological activity (see for example Cantwell and Piscitello, 2005). However, our evidence shows that the intensity of localized R\&D expenditures and the availability of human resources in science and technology to be particularly strong pull-factors for the EEMNEs' location choice.

\section{Conclusion}

Our paper investigated the sub-national location choice of a large sample of foreign affiliates that located in EU regions between 1996 and 2010. Applying different logit estimation approaches, we attempted to isolate significant differences in the location pattern of investors from emerging markets by employing an identification strategy that uses other investors as a control group. Our results obtained seem to be robust when relaxing restrictive model assumptions and accounting for host country, sector and firm specific effects as well as potential sample bias.

Our paper contributes by producing novel evidence that the location choice of EEMNEs in the EU is positively related to various sources of agglomeration economies and knowledge externalities. We can show that emerging market investors differ in their valuation of selected location factors from developed countries investors and that there is also some degree of heterogeneity within the group of emerging market investors. During the observation period, we find that, compared to developed countries investors, emerging market investors give more consideration to diversity externalities, urbanization economies and knowledge spillover from localized R\&D and human resources in science and technology occupations when choosing a location within EU countries. Furthermore, we can show a specific substitution pattern between

sub-national regions for emerging markets investor, which seems to be driven by diversity externalities and human capital related factors. 
From a theoretical point of view, our findings seem to support the argument that investors from emerging market economies use foreign direct investment to implement knowledge and asset seeking type of strategies in order to augment their ownership specific assets. This process can be modelled using the propositions of the technological accumulation approach towards firms' internationalization, which does not rely upon ex ante ownership specific advantages as a condition for firms' internationalization, but instead argues that these are endogenously created by firms' strategic investment in multiple foreign locations. This approach allows for economies of scale from transfer of innovation within the MNE network as well as the possibility to benefit from external economies in foreign location. In fact, our findings showed that location bound external economies do affect the location choice of emerging market multinational quite significantly. Whether EEMNEs also effectively absorb these externalities, generate reverse technology transfer and to which extent this in turn increases the rate of their innovation and profitability seems to be a decisive matter to be addressed in future research.

Our study might offer a few managerial implications: First, our results confirm that the internationalization of firms is also determined by the quality of sub-national location factors including spatially bounded agglomeration economies and knowledge externalities. This seems to be of particular importance to knowledge-seeking investment, since agglomeration economies and knowledge externalities serve as sources for local learning and competence creation. Second, given that some of these externalities develop only over long periods of time and are embedded in a complex institutional setting, they provide a strong incentive for internationalization.

Our empirical analysis also offers policy implications: First, spatially bounded agglomeration economies and knowledge externalities matter for both, developed and emerging market investors but to a different extent. In general, policies that foster the creation of such spillovers increase the attractiveness of EU regions to foreign investors. Second, it seems important for the design of investment promotion services to take into consideration that emerging market investors favor regions that offer urbanization economies and human resources in science and technology occupations. This seems to be particularly relevant, since the increasing importance of emerging market economies could play an important role for re-enforcing existing agglomeration economies and (knowledge-driven) investment within the EU27. 


\section{References:}

Alcácer, J., \& Chung, W. (2007). Location strategies and knowledge spillovers. Management Science, 53(5), 760-776.

Arrow, K. J. (1962). The economic implications of learning by doing. The Review of Economic Studies, 29(3), 155-173.

Audretsch, B., \& Feldman, M. P. (1996). R\&D spillovers and the geography of innovation and production. American Economic Review, 86(3), 630-640.

Barrios, S., Görg, H., \& Strobl, E. (2006). Multinationals' location choice, agglomeration economies and public incentives. International Regional Science Review, 29(1), 81-107.

Basile, R. (2004). Acquisition versus greenfield investment: the location of foreign manufacturers in Italy. Regional Science and Urban Economics, 34, 3-25.

Basile, R., Castellani, D., \& Zanfei, A. (2008). Location choices of multinational firms in Europe: The role of EU cohesion policy. Journal of International Economics, 74, 328-340.

Batista, R., \& Swan, P. (1998). Do firms in clusters innovate more? Research Policy, 27, 525540.

Beugelsdijk, S., \& Mudambi, R. (2013). MNEs as border-crossing multi-location enterprises: The role of discontinuities in geographic space. Journal of International Business Studies, 44(5), 413-426.

Buckley P. J., \& Casson, M. (1976). The future of multinational enterprise. London: MacMillan.

Buckley P. J., Clegg, J., Cross, A., Liu, X., Voss, H., \& Zheng, P. (2007). The determinants of Chinese outward FDI. Journal of International Business Studies, 38(4), 499-518.

Cantwell, J. A. (1989). Technological innovation and multinational corporations. Oxford: Basil Blackwell.

Cantwell, J. A. (1995). The globalisation of technology: What remains of the product cycle model? Cambridge Journal of Economics, 19, 155-174.

Cantwell, J. A. (2009). Location and the multinational enterprise. Journal of International Business Studies, 40, 35-41.

Cantwell, J. A., \& Iammarino, S. (1998). MNCs, technological innovation and regional systems in the EU: Some evidence in the Italian case. International Journal of the Economics of Business, 5, 383-408. 
Cantwell, J. A., \& Iammarino, S. (2000). Multinational corporations and the location of technological innovation in the UK regions. Regional Studies, 34(3), 317-322.

Cantwell, J. A., \& Piscitello, L. (2000). Accumulating technological competence: It's changing impact of corporate diversification and internationalization. Industrial and Corporate Change, 9, 21-51.

Cantwell, J. A., \& Piscitello, L. (2002). The location of technological activities of MNCs in European regions: The role of spillovers and local competencies. Journal of International Management, 8(1), 69-96.

Cantwell, J. A., \& Piscitello, L. (2005). Recent location of foreign-owned research and development activities by large multinational corporations in the European regions: The role of spillovers and externalities. Regional Studies, 39(1), 1-16.

Cantwell, J. A., \& Piscitello, L. (2014). Historical changes in the determinants of the composition of innovative activity in MNC subunits. Industrial and Corporate Change, 23(3), 633-660.

Carlton, D. (1979). Why new firms locate where they do: an econometric model. In W. Wheaton (Ed.), Interregional movements and regional growth (pp. 13-50). Washington, DC: Urban Institute.

Caves, R. E. (1971). International corporations: The industrial economics of foreign investment. Economica, 38 (149), 1-27.

Chandler, A. D. (1990). Scale and scope: the dynamics of industrial capitalism, Cambridge, MA: Harvard University Press.

Chidlow, A., Salciuviene, L., \& Young, S. (2009). Regional determinates of inward FDI distribution in Poland. International Business Review, 18(3), 119-133.

Child, J., \& Rodrigues, S. B. (2005). The internationalization of Chinese firms: A case for theoretical extension? Management and Organization Review, 1(3), 381-410.

Chung, W., \& Alcácer, J. (2002). Knowledge seeking and location choice of foreign direct investment in the United States. Management Science, 48(12), 1534-1554.

Clarke, J. E., Tamaschke, R., \& Liesch, P. (2012). International experience in international business research: A conceptualization and exploration of key themes. International Journal of Management Reviews, 15(3), 265-279. 
Cohen, W. M., \& Levinthal, D. A. (1990). Absorptive capacity: a new perspective on learning and innovation. Administrative Science Quarterly, 35, 128-52.

Cooke, P. (2001). Regional innovation systems, clusters and the knowledge economy. Industrial and Corporate Change, 10(4), 945-974.

Crozet M., Mayer, T., \& Mucchielli, J. L. (2004). How do firms agglomerate? A study of FDI in France. Regional Science and Urban Economics, 34, 27-54.

Cuervo-Cazurra, A. (2008). The multinationalization of developing country MNEs: the case of Multilatinas. Journal of International Management, 14, 138-154.

Devereux, M., \& Griffith, R. (1998). Taxes and location of production: Evidence from a panel of US multinationals. Journal of Public Economics, 68(3), 335-367.

Devereux, M., Griffith, R., \& Simpson, H. (2007). Firm location decisions, regional grants and agglomeration externalities. Journal of Public Economics, 91(3-4), 413-435.

Dicken, P., \& Lloyd, P.E. (1990). Location in space. Theoretical perspectives in economic geography. (3rd ed.). New York: Harper Collins.

Disdier, A. C., \& Mayer, T. (2004). How different is Eastern Europe? Structures and determinants of location choices by French firms in Eastern and Western Europe. Journal of Comparative Economics, 32(2), 280-296.

Dunning, J. H. (1977). Trade, location of economic activity and the MNE: A search for an eclectic approach. In B. Ohlin, P.O. Hesselborn, \& P.M. Wijkman (Eds.), The international allocation of economic activity (pp. 395-418). London and Basingstoke: Macmillan.

Dunning, J.H. (1981). International production and the multinational enterprise. London: George Allen and Unwin.

Dunning, J. H. (1998). Location and the multinational enterprise: A neglected factor? Journal of International Business Studies, 29(1), 45-66.

Dunning, J. H. (2006). Comments on dragon multinationals. Asia Pacific Journal of Management, 23, 139-141.

Eurostat (2011). Regions in the European Union - Nomenclature of territorial units for statistics NUTS 2010/EU-27, Luxembourg: Eurostat Methodologies \& Working Papers.

Fallon, G., \& Cook, M. (2010). Exploring the regional distribution of inbound foreign direct investment in the UK in theory and practice: evidence from a five-region study. Regional Studies, 44(3), 337-353. 
Feldman, M. P. (1994). The geography of innovation. Dordrecht: Kluwer Academic Publishers.

Feldman, M., \& Audretsch, D. (1999). Innovation in cities: Science-based diversity, specialization and localized competition. European Economic Review, 43(2), 409-429.

Florida, R. (1997). The globalization of R\&D: Results of a survey of foreign-affiliated R\&D laboratories in the USA. Research Policy, 26 (1), 85-103.

Frost, T. S. (2001). The geographic sources of foreign subsidiaries' innovation. Strategic Management Journal, 22, 101-123.

Fujita, M., Krugman, P., \& Venables, A. J. (1999). The spatial economy: Cities, regions and international trade. Cambridge, MA: MIT Press.

Glaeser, E. L., Kallal, H. D., Scheinkman, J. A., \& Shleifer, A. (1992). Growth in cities. Journal of Political Economy, 100, 1126-1152.

Goldstein, A. (2007). Multinational companies from emerging markets. Houndmills: Palgrave Macmillan.

Grandstrand, O., \& Sjölander, S., (1992). Internationalisation and diversification of multitechnology corporations. In O. Granstrand, L. Hakanson, \& S. Sjölander (Eds.), Technology management and international business: Internationalisation of $R \& D$ and technology. London: Wiley, 181-207.

Grandstrand, O., Patel, P., \& Pavitt, K. (1997). Multi-technology corporations: why they have 'distributed' rather than 'distinctive' core competencies. California Management Review, 39, $8-25$.

Guimarães, P., Figueiredo, O., \& Woodward, D. (2000). Agglomeration and the location of foreign direct investment in Portugal. Journal of Urban Economics, 47, 115-135.

Head, K., Ries, J., \& Swenson, D. (1999). Attracting foreign manufacturing: Investment promotion and agglomeration. Regional Science and Urban Studies, 29(2), 197-216.

Heiss, F. (2002). Structural choice analysis with nested logit models. Stata Journal, 2(3), $227-$ 252.

Hennart, J. F. (2012). Emerging market multinationals and the theory of the multinational enterprise. Global Strategy Journal, 2(3), 168-187.

Hilbert, C. A. L., \& Voicu, I. (2010). Agglomeration economics and the location of foreign direct investment: Empirical evidence from Romania. Regional Studies, 44(3), 355-371. 
Hoskisson, R. E., Eden, L., Lau, C. M., \&Wright, M. (2000). Strategy in emerging economies. The Academy of Management Journal, 43(3), 249-267.

Howells, J. (1990). The location and organization of research and development: New horizons. Research Policy, 19(2), 133-146.

Hymer, S. H. (1976). The international operations of national firms: A study of direct investment. Cambridge, MA: MIT Press.

Jacobs, J. (1969). The economy of cities. London: Jonathan Cape.

Jaffe, A., Trajtenberg, M., \& Henderson, R. (1993). Geographical localisation of knowledge spillovers, as evidenced by patent citations. Quarterly Journal of Economics, 58, 577-598.

Johanson, J., \& Vahlne, J. E. (1977). The international process of the firm: A model of knowledge development and increasing foreign market commitments. Journal of International Business Studies, 8(1), 23-32.

Johanson, J., \& Vahlne, J. E. (2009). The Uppsala internationalization process model revisited: From liability of foreignness to liability of outsidership. Journal of International Business Studies, 40(9), 1411-1431.

Kedia, B., Gaffney, N., \& Clampit, J. (2012). EEMNEs and knowledge-seeking FDI. Management International Review, 52(2), 155-173.

Kogut, B. (1985). Designing global strategies: Profiting from operational flexibility. Sloan Management Review, 27(1), 27-38.

Kogut, B., \& Chang, S. J. (1991). Technological capabilities and Japanese foreign direct investment in the United States. Review of Economics and Statistics, 73(3), 401-413.

Krugman, P. (1991). Increasing returns and economic geography. Journal of Political Economy, 99, 483-499.

Kuemmerle, W. (1997). Building effective R\&D capabilities abroad. Harvard Business Review, March-April, 61-70.

Kuemmerle, W. (1999). The drivers of foreign direct investment into research and development: An empirical investigation. Journal of International Business Studies, 30(1), 1-24.

Kumar, N. (1998). Multinational enterprises, regional economic integration, and export-platform production in the host countries: An empirical analysis for the US and Japanese corporations. Review of World Economics, 134(3), 450-83.

Lall, S. (1983). The new multinationals. Chichester and New York: John Wiley. 
Lessard, D., \& Lucea, R. (2009). Mexican multinationals: Insights from CEMEX. In R.

Ramamurti, \& J. V. Singh (Eds.), Emerging multinationals in emerging markets (pp. 280311). New York: Cambridge University Press.

Li, P. P. (2010). Toward a learning-based view of internationalization: The accelerated trajectories of cross-border learning for latecomers. Journal of International Management, 16, 43-59.

Luo, Y. D., \& Rui, H. (2009). An ambidexterity perspective toward multinational enterprises from emerging economies. Academy of Management Perspective, 23(4), 49-70.

Luo, Y. D., \& Tung, R. L. (2007). International expansion of emerging market enterprises: A springboard perspective. Journal of International Business Studies, 38(4), 481-498.

Luo, Y. D., Zhao, H. X., Wang, Y. H., \& Xi, Y. M. (2011). Venturing abroad by emerging market enterprises. A test of dual strategic intents. Management International Review, 51(4), 433-460.

Madhok, A., \& Keyhani, M. (2012). Acquisitions as entrepreneurship: Asymmetries, opportunities, and the internationalization of multinationals from emerging economies. Global Strategy Journal, 2, 26-40.

Makino, S., Lau, C., \& Yeh, R. (2002). Asset-exploitation versus asset-seeking: Implications for location choice of foreign direct investment from newly industrialized economies. Journal of International Business Studies, 33(3), 403-421.

Malecki, J. (1985). Industrial location and corporate organization in high technology industries. Economic Geography, 61(4), 345-369.

Mariotti, S., \& Piscitello, L. (1995). Information costs and location of FDIs within the host country: Empirical evidence from Italy. Journal of International Business Studies, 26(4), 815.

Mariotti, S., Elia, S., \& Piscitello, L. (2010). Spatial agglomeration of MNEs: The role of information externalities and spatial spillovers. Journal of Economic Geography, 10(4), 519538.

Markusen, J., \& Venables, A. (1999). Foreign direct investment as a catalyst for industrial development. European Economic Review, 43, 335-356.

Marshall, A. (1890). Principles of economics. London: McMillan.

Mathews, J. A. (2002). Competitive advantages of the latecomer firm: A resource-based account of industrial catch-up strategies. Asia Pacific Journal of Management, 19(4), 467-488. 
Mathews, J. A. (2006). Dragon multinationals: New players in 21 st century globalization. Asia Pacific Journal of Management, 23(1), 5-27.

McCann, P. (2011). International business and economic geography: knowledge, time and transactions costs. Journal of Economic Geography, 11(2), 309-317.

McCann, P., \& Mudambi, R. (2005). Analytical differences in the economics of geography: The case of the multinational firm. Environment and Planning A, 37(10), 1857-1876.

McFadden, D. (1974). Conditional logit analysis of qualitative behaviour. In P. Zarembka (Ed.), Frontiers in econometrics (pp. 105-142). New York: Academic Press.

McFadden, D., \& Train, K. (2000). Mixed MNL Models of Discrete Response. Journal of Applied Econometrics, 15, 447-470.

Narula, R. (2012). Do we need different frameworks to explain infant MNEs from developing countries? Global Strategy Journal, 2, 188-204.

Nelson, R. R., \& Rosenberg, N. (1999). Science, technological advance and economic growth. In A. D. Chandler, P. Hagström \& Ö. Sölvell (Eds.), The dynamic firm: the role of technology, strategy, organization, and regions (pp. 15-44). Oxford and New York: Oxford University Press.

Paci, R., \& Usai, S. (2000). Externalities, knowledge spillovers and the spatial distribution of innovation. GeoJournal, 49, 381-390.

Porter, M. E. (1990). The competitive advantage of nations. New York: Free Press.

Ramamurti, R., \& Singh, J. (2009). Emerging market multinationals in emerging markets. Cambridge, MA: Cambridge University Press.

Ramamurti, R. (2009). Why study emerging-market multinationals? In R. Ramamurti, \& J. V. Singh (Eds.), Emerging multinationals in emerging markets (pp. 3-22). Cambridge:

Cambridge University Press.

Ramamurti, R. (2012). What is really different about emerging market multinationals? Global Strategy Journal, 1, 41-47.

Richardson, H. W. (1969). Elements of regional economics. Harmondsworth (UK): Penguin.

Romer, P. M. (1986). Increasing returns and long run growth. Journal of Political Economy, 94, $1002-37$.

Rosenthal, S., \& Strange, W. (2000). Geography, industrial organization and agglomeration. Syracuse, NY: Syracuse University Press. 
Rugman, A. M. (2009). Theoretical aspects of MNEs from emerging economies. In R.

Ramamurti, \& J. V. Singh (Eds.), Emerging multinationals in emerging markets (pp. 42-63).

Cambridge, MA: Cambridge University Press.

Song, J., Almeida, P., \& Wu, G. (2003). Learning-by-hiring: When is mobility more likely to facilitate interfirm knowledge transfer? Management Science, 49(4), 351-365.

Teece, D. J. (1986). Profiting from technological innovation: Implications for integration collaboration licensing and public policy. Research Policy, 15, 285-305.

Train, K. E. (2003). Discrete choice methods with simulation. Cambridge, MA: Cambridge University Press.

UNCTAD (2011). World Investment Report 2011: Non-equity modes of international production and development. New York and Geneva: United Nations.

Venables, A. J. (1996). Equilibrium locations of vertically linked industries. International Economic Review, 37, 341-359.

Wells, L. Jr. (1983). Third world multinationals: The rise of foreign investment from developing countries. Cambridge, MA, London, England: MIT Press.

Zhou, L., Wu, W.-P., \& Luo, X. (2007). Internationalization and the performance of born-global SMEs: The mediating role of social networks. Journal of International Business Studies, 38(4), 673-690. 


\begin{tabular}{|c|c|c|c|}
\hline \multicolumn{4}{|c|}{ ANNEX } \\
\hline Developed & Countries & Emerging E & conomies \\
\hline EU-15 & Non-EU & EU-12 & Non-EU \\
\hline $\begin{array}{l}\text { Austria } \\
\text { Belgium } \\
\text { Denmark } \\
\text { Finland } \\
\text { France } \\
\text { Germany } \\
\text { Greece } \\
\text { Ireland } \\
\text { Italy } \\
\text { Luxembourg } \\
\text { Netherlands } \\
\text { Portugal } \\
\text { Spain } \\
\text { Sweden } \\
\text { United } \\
\text { Kingdom }\end{array}$ & $\begin{array}{l}\text { Australia } \\
\text { Canada } \\
\text { Iceland } \\
\text { Japan } \\
\text { New Zealand } \\
\text { Norway } \\
\text { San Marino } \\
\text { Switzerland } \\
\text { United States }\end{array}$ & $\begin{array}{l}\text { Bulgaria } \\
\text { Cyprus } \\
\text { Czech } \\
\text { Republic } \\
\text { Estonia } \\
\text { Hungary } \\
\text { Latvia } \\
\text { Lithuania } \\
\text { Malta } \\
\text { Poland } \\
\text { Romania } \\
\text { Slovakia } \\
\text { Slovenia }\end{array}$ & $\begin{array}{l}\text { Algeria } \\
\text { Argentina } \\
\text { Brazil } \\
\text { Chile } \\
\text { China } \\
\text { Egypt } \\
\text { Hong Kong } \\
\text { India } \\
\text { Indonesia } \\
\text { Israel } \\
\text { Jordan } \\
\text { Malaysia } \\
\text { Mexico } \\
\text { Morocco } \\
\text { Pakistan } \\
\text { Peru } \\
\text { Philippines } \\
\text { Russia } \\
\text { Saudi Arabia } \\
\text { Singapore } \\
\text { South Africa } \\
\text { South Korea } \\
\text { Taiwan } \\
\text { Thailand } \\
\text { Turkey } \\
\text { Ukraine } \\
\text { Yemen }\end{array}$ \\
\hline
\end{tabular}


Table A2 Annual entry rates by country of investor origin

\begin{tabular}{c|cccc|cccc}
\hline \multirow{2}{*}{ Year } & \multicolumn{4}{|c|}{ Developed Countries } & \multicolumn{3}{c}{ Emerging Economies } \\
& No. & $\%$ & No. & $\%$ & No. & $\%$ & No. & $\%$ \\
\hline 1996 & 1272 & 6.91 & 684 & 7.05 & 81 & 5.01 & 153 & 5.16 \\
1997 & 1408 & 7.65 & 727 & 7.49 & 102 & 6.31 & 155 & 5.23 \\
1998 & 1445 & 7.85 & 798 & 8.23 & 95 & 5.88 & 180 & 6.07 \\
1999 & 1589 & 8.63 & 877 & 9.04 & 105 & 6.49 & 184 & 6.21 \\
2000 & 1712 & 9.30 & 962 & 9.92 & 116 & 7.17 & 213 & 7.19 \\
2001 & 1332 & 7.24 & 753 & 7.76 & 108 & 6.68 & 197 & 6.65 \\
2002 & 1194 & 6.49 & 704 & 7.26 & 92 & 5.69 & 206 & 6.95 \\
2003 & 1124 & 6.11 & 632 & 6.51 & 95 & 5.88 & 198 & 6.68 \\
2004 & 1306 & 7.10 & 699 & 7.20 & 127 & 7.85 & 206 & 6.95 \\
2005 & 1336 & 7.26 & 669 & 6.90 & 121 & 7.48 & 238 & 8.03 \\
2006 & 1296 & 7.04 & 619 & 6.38 & 111 & 6.86 & 280 & 9.45 \\
2007 & 1236 & 6.72 & 554 & 5.71 & 142 & 8.78 & 252 & 8.50 \\
2008 & 906 & 4.92 & 413 & 4.26 & 130 & 8.04 & 219 & 7.39 \\
2009 & 617 & 3.35 & 316 & 3.26 & 88 & 5.44 & 135 & 4.55 \\
2010 & 629 & 3.42 & 295 & 3.04 & 104 & 6.43 & 148 & 4.99 \\
& \multicolumn{7}{|c|}{ Source: Own calculations, AMADEUS Database (2012) } \\
Total & $\mathbf{1 8 , 4 0 2}$ & $\mathbf{1 0 0}$ & $\mathbf{9 , 7 0 2}$ & $\mathbf{1 0 0}$ & $\mathbf{1 , 6 1 4}$ & $\mathbf{1 0 0}$ & $\mathbf{2 , 9 6 4}$ & $\mathbf{1 0 0}$ \\
\hline
\end{tabular}

Table A3 Sectoral structure of foreign affiliates by country of investor origin

\begin{tabular}{|c|c|c|c|c|c|c|c|c|c|c|}
\hline \multirow{3}{*}{ Sector } & \multirow{2}{*}{\multicolumn{2}{|c|}{ Total }} & \multicolumn{4}{|c|}{ Developed Countries } & \multicolumn{4}{|c|}{ Emerging Economies } \\
\hline & & & \multicolumn{2}{|c|}{ EU15 } & \multicolumn{2}{|c|}{ Non-EU } & \multicolumn{2}{|c|}{ EU12 } & \multicolumn{2}{|c|}{ Non-EU } \\
\hline & No. & $\%$ & No. & $\%$ & No. & $\%$ & No. & $\%$ & No. & $\%$ \\
\hline Manufacturing* & 9356 & 28.62 & 5750 & 31.25 & 2488 & 25.64 & 353 & 21.87 & 765 & 25.81 \\
\hline Services** & 22852 & 69.92 & 12396 & 67.36 & 7093 & 73,11 & 1234 & 76.46 & 2129 & 71,83 \\
\hline Other*** & 477 & 1.46 & 256 & 1.39 & 121 & 1.25 & 27 & 1.67 & 70 & 2.36 \\
\hline Total & 32,685 & 100 & 18,402 & 100 & 9,702 & 100 & 1,614 & 100 & 2,964 & 100 \\
\hline
\end{tabular}

Note: *NACE Rev.2: 1-9; ** NACE Rev.2: 10-00; *** NACE Rev.2: 35-98

Source: Own calculations, AMADEUS Database (2012) 
Table A4 Affiliates distribution across host countries by group of source countries

\begin{tabular}{|c|c|c|c|c|c|c|}
\hline \multirow[b]{2}{*}{ Host country } & \multicolumn{2}{|c|}{ Total } & \multicolumn{2}{|c|}{ DCMNE } & \multicolumn{2}{|c|}{ EEMNE } \\
\hline & Frequency & $\%$ & Frequency & $\%$ & Frequency & $\%$ \\
\hline Austria & 846 & 2,59 & 787 & 2,80 & 59 & 1,30 \\
\hline Belgium & 771 & 2,36 & 739 & 2,63 & 32 & 0,70 \\
\hline Bulgaria & 358 & 1,10 & 247 & 0,88 & 111 & 2,44 \\
\hline Cyprus & 25 & 0,08 & 18 & 0,06 & 7 & 0,15 \\
\hline Czech Republic & 883 & 2,70 & 664 & 2,36 & 217 & 4,76 \\
\hline Germany & 3842 & 11,75 & 3454 & 12,29 & 388 & 8,52 \\
\hline Denmark & 536 & 1,64 & 516 & 1,84 & 20 & 0,44 \\
\hline Estonia & 432 & 1,32 & 364 & 1,30 & 67 & 1,47 \\
\hline Spain & 2420 & 7,40 & 2247 & 8,00 & 172 & 3,78 \\
\hline Finland & 383 & 1,17 & 360 & 1,28 & 23 & 0,50 \\
\hline France & 2897 & 8,86 & 2688 & 9,56 & 195 & 4,28 \\
\hline Greece & 419 & 1,28 & 289 & 1,03 & 130 & 2,85 \\
\hline Hungary & 356 & 1,09 & 331 & 1,18 & 25 & 0,55 \\
\hline Ireland & 443 & 1,36 & 412 & 1,47 & 31 & 0,68 \\
\hline Italy & 1766 & 5,40 & 1650 & 5,87 & 116 & 2,55 \\
\hline Lithuania & 486 & 1,49 & 355 & 1,26 & 131 & 2,88 \\
\hline Luxembourg & 176 & 0,54 & 160 & 0,57 & 16 & 0,35 \\
\hline Latvia & 368 & 1,13 & 228 & 0,81 & 137 & 3,01 \\
\hline Malta & 12 & 0,04 & 12 & 0,04 & 211 & 4,63 \\
\hline Netherlands & 1528 & 4,67 & 1317 & 4,69 & 199 & 4,37 \\
\hline Poland & 1965 & 6,01 & 1765 & 6,28 & 26 & 0,57 \\
\hline Portugal & 465 & 1,42 & 439 & 1,56 & 1176 & 25,82 \\
\hline Romania & 4397 & 13,45 & 3219 & 11,45 & 27 & 0,59 \\
\hline Sweden & 794 & 2,43 & 767 & 2,73 & 30 & 0,66 \\
\hline Slovenia & 173 & 0,53 & 143 & 0,51 & 56 & 1,23 \\
\hline Slovakia & 214 & 0,65 & 158 & 0,56 & 953 & 20,92 \\
\hline Great Britain & 5730 & 17,53 & 4775 & 16,99 & 59 & 1,30 \\
\hline Total & 32,685 & 100 & 28,104 & 100 & 4,555 & 100 \\
\hline
\end{tabular}


Table A5 Distribution of foreign affiliates across sub-national (NUTS-1) regions within the EU27

\begin{tabular}{|c|c|c|c|c|c|c|c|c|c|c|c|c|c|c|c|c|c|}
\hline \multirow[t]{2}{*}{$\mathbf{N U T S}^{\mathbf{1}}$} & \multicolumn{2}{|c|}{ DCMNE } & \multicolumn{2}{|c|}{ EEMNE } & \multirow[b]{2}{*}{ Diff. } & \multicolumn{3}{|c|}{ DCMNE } & \multicolumn{2}{|c|}{ EEMNE } & \multirow[b]{2}{*}{ Diff. } & \multicolumn{3}{|c|}{ DCMNE } & \multicolumn{2}{|c|}{ EEMNE } & \multirow[b]{2}{*}{ Diff. } \\
\hline & No. & $\%$ & No. & $\%$ & & & No. & $\%$ & No. & $\%$ & & & No. & $\%$ & No. & $\%$ & \\
\hline AT1 & 373 & 1.33 & 29 & 0.64 & -0.69 & ES6 & 140 & 0.50 & 13 & 0.29 & - & PL2 & 303 & 1.08 & 29 & 0.64 & -0.44 \\
\hline AT2 & 121 & 0.43 & 12 & 0.26 & -0.17 & ES7 & 49 & 0.17 & 11 & 0.24 & 0.07 & PL3 & 80 & 0.28 & 17 & 0.37 & 0.09 \\
\hline AT3 & 293 & 1.04 & 18 & 0.40 & -0.65 & FI1 & 360 & 1.28 & 23 & 0.50 & - & PL4 & 297 & 1.06 & 21 & 0.46 & -0.60 \\
\hline BE1 & 179 & 0.64 & 5 & 0.11 & -0.53 & FR1 & 1239 & 4.41 & 80 & 1.76 & - & PL5 & 198 & 0.70 & 20 & 0.44 & -0.27 \\
\hline BE2 & 441 & 1.57 & 20 & 0.44 & -1.13 & FR2 & 311 & 1.11 & 23 & 0.50 & - & PL6 & 150 & 0.53 & 20 & 0.44 & -0.09 \\
\hline BE3 & 119 & 0.42 & 7 & 0.15 & -0.27 & FR3 & 165 & 0.59 & 7 & 0.15 & - & PT1 & 439 & 1.56 & 26 & 0.57 & -0.99 \\
\hline BG3 & 69 & 0.25 & 49 & 1.08 & 0.83 & FR4 & 221 & 0.79 & 6 & 0.13 & - & RO1 & 965 & 3.43 & 251 & 5.51 & 2.08 \\
\hline BG4 & 178 & 0.63 & 62 & 1.36 & 0.73 & FR5 & 141 & 0.50 & 25 & 0.55 & 0.05 & $\mathrm{RO} 2$ & 347 & 1.23 & 141 & 3.10 & 1.86 \\
\hline CY0 & 18 & 0.06 & 7 & 0.15 & 0.09 & FR6 & 131 & 0.47 & 8 & 0.18 & - & $\mathrm{RO} 3$ & 1301 & 4.63 & 693 & 15.21 & 10.58 \\
\hline $\mathrm{CZ0}$ & 664 & 2.36 & 217 & 4.76 & 2.40 & FR7 & 268 & 0.95 & 21 & 0.46 & - & RO4 & 606 & 2.16 & 91 & 2.00 & -0.16 \\
\hline DE1 & 435 & 1.55 & 42 & 0.92 & -0.63 & FR8 & 212 & 0.75 & 25 & 0.55 & - & SE1 & 467 & 1.66 & 19 & 0.42 & -1.24 \\
\hline DE2 & 613 & 2.18 & 54 & 1.19 & -1.00 & GR1 & 21 & 0.07 & 10 & 0.22 & 0.14 & SE2 & 231 & 0.82 & 6 & 0.13 & -0.69 \\
\hline DE3 & 154 & 0.55 & 33 & 0.72 & 0.18 & GR2 & 14 & 0.05 & 4 & 0.09 & 0.04 & SE3 & 69 & 0.25 & 2 & 0.04 & -0.20 \\
\hline DE4 & 63 & 0.22 & 9 & 0.20 & -0.03 & GR3 & 250 & 0.89 & 113 & 2.48 & 1.59 & SI0 & 143 & 0.51 & 30 & 0.66 & 0.15 \\
\hline DE5 & 40 & 0.14 & 4 & 0.09 & -0.05 & GR4 & 4 & 0.01 & 3 & 0.07 & 0.05 & SK0 & 158 & 0.56 & 56 & 1.23 & 0.67 \\
\hline DE6 & 178 & 0.63 & 26 & 0.57 & -0.06 & HU1 & 211 & 0.75 & 18 & 0.40 & - & UKC & 89 & 0.32 & 17 & 0.37 & 0.06 \\
\hline DE7 & 457 & 1.63 & 46 & 1.01 & -0.62 & HU2 & 72 & 0.26 & 3 & 0.07 & - & UKD & 304 & 1.08 & 96 & 2.11 & 1.03 \\
\hline DE8 & 38 & 0.14 & 8 & 0.18 & 0.04 & HU3 & 48 & 0.17 & 4 & 0.09 & - & UKE & 236 & 0.84 & 44 & 0.97 & 0.13 \\
\hline DE9 & 197 & 0.70 & 28 & 0.61 & -0.09 & IE0 & 412 & 1.47 & 31 & 0.68 & - & UKF & 226 & 0.80 & 38 & 0.83 & 0.03 \\
\hline DEA & 807 & 2.87 & 83 & 1.82 & -1.05 & ITC & 960 & 3.42 & 66 & 1.45 & - & UKG & 317 & 1.13 & 46 & 1.01 & -0.12 \\
\hline DEB & 94 & 0.33 & 8 & 0.18 & -0.16 & ITD & 332 & 1.18 & 24 & 0.53 & - & UKH & 328 & 1.17 & 64 & 1.41 & 0.24 \\
\hline DEC & 40 & 0.14 & 3 & 0.07 & -0.08 & ITE & 270 & 0.96 & 21 & 0.46 & - & UKI & 1872 & 6.66 & 410 & 9.00 & 2.34 \\
\hline DED & 100 & 0.36 & 9 & 0.20 & -0.16 & ITF & 60 & 0.21 & 5 & 0.11 & - & UKJ & 835 & 2.97 & 140 & 3.07 & 0.10 \\
\hline DEE & 79 & 0.28 & 17 & 0.37 & 0.09 & ITG & 28 & 0.10 & 0 & 0.00 & - & UKK & 218 & 0.78 & 32 & 0.70 & -0.07 \\
\hline DEF & 88 & 0.31 & 9 & 0.20 & -0.12 & LT0 & 355 & 1.26 & 131 & 2.88 & 1.61 & UKL & 109 & 0.39 & 23 & 0.50 & 0.12 \\
\hline DEG & 71 & 0.25 & 9 & 0.20 & -0.06 & LU0 & 160 & 0.57 & 16 & 0.35 & - & UKM & 193 & 0.69 & 34 & 0.75 & 0.06 \\
\hline DK0 & 516 & 1.84 & 20 & 0.44 & -1.40 & LV0 & 228 & 0.81 & 137 & 3.01 & 2.20 & UKN & 48 & 0.17 & 9 & 0.20 & 0.03 \\
\hline EE0 & 364 & 1.30 & 67 & 1.47 & 0.18 & MT0 & 12 & 0.04 & 0 & 0.00 & - & & & & & & \\
\hline ES1 & 98 & 0.35 & 5 & 0.11 & -0.24 & NL1 & 50 & 0.18 & 6 & 0.13 & - & Total & 28,104 & 100 & 4,555 & 100 & \\
\hline ES2 & 210 & 0.75 & 18 & 0.40 & -0.35 & NL2 & 180 & 0.64 & 18 & 0.40 & - & & & & & & \\
\hline ES3 & 898 & 3.20 & 69 & 1.51 & -1.68 & NL3 & 810 & 2.88 & 145 & 3.18 & 0.30 & & & & & & \\
\hline ES4 & 92 & 0.33 & 4 & 0.09 & -0.24 & NL4 & 277 & 0.99 & 42 & 0.92 & - & & & & & & \\
\hline ES5 & 760 & 2.70 & 52 & 1.14 & -1.56 & PL1 & 737 & 2.62 & 92 & 2.02 & - & & & & & & \\
\hline
\end{tabular}

Note: ${ }^{1}$ NUTS-1 level codes correspond to the official classification by EUROSTAT. Source: Own calculations, AMADEUS Database (2012) 
Table A6 List of variables

\begin{tabular}{|c|c|c|}
\hline Variables & Symbol & Definitions \\
\hline Dependent & & \\
\hline Choice & & $\begin{array}{l}\text { Binary variable for choice from a given set of alternatives (regions) } \\
0 \text { : no entry into region, } 1 \text { : entry into region }\end{array}$ \\
\hline Independent & & (alternative specific variables) \\
\hline $\begin{array}{l}\text { Industry } \\
\text { specialization }\end{array}$ & Specialization & $\begin{array}{l}\text { Natural logarithm of regional industry specialization, computed i } \\
\text { terms of the share of value added of a given industry (NACE } 2 \text { dig } \\
\text { level) over total gross value added (deflated in Euro 2000) within th } \\
\text { given region }{ }^{1} \text { (variable is industry and region specific) }\end{array}$ \\
\hline $\begin{array}{l}\text { Regional } \\
\text { Diversification }\end{array}$ & Diversification & $\begin{array}{l}\text { Natural logarithm of Herfindahl-Index, computed as the sum of th } \\
\text { squared share of the value added of all industries (NACE } 2 \text { dig } \\
\text { level) within the given region (variable is region specific) }\end{array}$ \\
\hline Urbanization & Density & $\begin{array}{l}\text { Natural logarithm of the number of inhabitants (in thousands) pe } \\
\text { square kilometer (variable is region specific) }\end{array}$ \\
\hline R\&D & $\mathrm{R} \& \mathrm{D}$ & $\begin{array}{l}\text { Natural logarithm of total } \mathrm{R} \& \mathrm{D} \text { expenditure as percentage of th } \\
\text { regional } \mathrm{GDP}^{2} \text { (variable is region specific) }\end{array}$ \\
\hline $\begin{array}{l}\text { Human Capital } \\
\text { related Technology }\end{array}$ & Technology & $\begin{array}{l}\text { Natural logarithm the share of the human resources in science an } \\
\text { technology occupations of total employment within the give } \\
\text { industry and region }{ }^{2} \text { (variable is industry and region specific) }\end{array}$ \\
\hline Demand & Market Size & $\begin{array}{l}\text { Natural logarithm GDP (in Millions Euro) within the given region } \\
\text { (variable is region specific) }\end{array}$ \\
\hline Labor Costs & Wage & $\begin{array}{l}\text { Natural logarithm hourly wage rate within industry and region } \\
\text { (variable is industry and region specific) }\end{array}$ \\
\hline Labor supply & Labor & $\begin{array}{l}\text { Natural logarithm of the share of tertiary students (ISCED5-6) ove } \\
\text { all students in a given region }{ }^{2} \text { (variable is region specific) }\end{array}$ \\
\hline Infrastructure & Infrastructure & $\begin{array}{l}\text { Natural logarithm of the total length of roads (in } \mathrm{km} \text { ) per } \mathrm{km}^{2} \text { in } \\
\text { given region }{ }^{2} \text { (variable is region specific) }\end{array}$ \\
\hline Geographic Distance & Distance & $\begin{array}{l}\text { Natural logarithm of the Euclidean distance (in } \mathrm{km} \text { ) between capita } \\
\text { of the given region and the capital }{ }^{4} \text { (variable is region specific) }\end{array}$ \\
\hline $\begin{array}{l}\text { Firm specific } \\
\text { characteristics }\end{array}$ & & (used for interaction terms with alternative specific variables) \\
\hline Sector & & $\begin{array}{l}\text { Dummy }=1 \text { if affiliate is in manufacturing (NACE Rev. } 2 \text { 10-33) } \\
\text { Dummy }=0 \text { if affiliate is in services (NACE Rev. } 2 \text { 35-98) }\end{array}$ \\
\hline Entry Mode & & $\begin{array}{l}\text { Dummy }=1 \text { if investor acquired affiliate by merger or acquisition } \\
\text { Dummy }=0 \text { if investor established affiliate as Greenfield }\end{array}$ \\
\hline Experience & & $\begin{array}{l}\text { Dummy }=1 \text { if investor had prior affiliate within host country } \\
\text { Dummy }=0 \text { if investor had no prior affiliate within host country }\end{array}$ \\
\hline
\end{tabular}

Note: ${ }^{1}$ IGEAT-Free University of Brussels (2012), ${ }^{2}$ EUROSTAT (2012), ${ }^{3}$ EU KLEMS (2012, for Bulgaria and

Romania OECD), ${ }^{\mathbf{4}}$ Own calculations, ${ }^{\mathbf{5}}$ AMADEUS (2012), ${ }^{\mathbf{6}}$ Zephyr Database; ${ }^{7}$ AMADEUS \& ORBIS (2014) 
Table A7 Correlation and collinearity statistics for explanatory variables

\begin{tabular}{|c|c|c|c|c|c|c|c|c|c|c|c|c|c|c|c|}
\hline Variable & Mean & Std. Dev. & Min & $\operatorname{Max}$ & 1 & 2 & 3 & 4 & 5 & 6 & $\overline{7}$ & 8 & 9 & 10 & VIF \\
\hline 1. Specialization & -2.968 & 1.247 & -11.513 & -0.717 & 1 & & & & & & & & & & 1.13 \\
\hline 2. Diversification & -2.449 & 0.217 & -2.847 & -1.332 & $-0.0755^{*}$ & 1 & & & & & & & & & 1.29 \\
\hline 3. Density & 5.103 & 1.134 & 1.775 & 8.810 & $0.0107 *$ & $0.4241^{*}$ & 1 & & & & & & & & 1.54 \\
\hline 4. $R \& D$ & 0.080 & 0.775 & -2.120 & 1.575 & $0.0569 *$ & $0.1736^{*}$ & $0.2618 *$ & 1 & & & & & & & 2.31 \\
\hline 5. Technology & 3.111 & 0.660 & -0.357 & 4.519 & $0.3135^{*}$ & $0.1233 *$ & $0.1070 *$ & 0.2090 & 1 & & & & & & 1.20 \\
\hline 6. Market & 11.020 & 1.093 & 8.012 & 13.239 & $0.0625^{*}$ & $0.1487^{*}$ & $0.2575^{*}$ & $0.6653 *$ & $0.0893 *$ & 1 & & & & & 2.45 \\
\hline 7. Wage & 2.480 & 0.934 & -0.941 & 5.056 & $0.0555^{*}$ & $0.2058 *$ & $0.2564 *$ & $0.6978 *$ & $0.1757 *$ & $0.6911 *$ & 1 & & & & 2.63 \\
\hline 8. Labor & 2.675 & 0.363 & 0.916 & 3.666 & $0.0217 *$ & $0.0276 *$ & $0.1000 *$ & $0.0391 *$ & $0.0233 *$ & $0.1866^{*}$ & $-0.0636^{*}$ & 1 & & & 1.19 \\
\hline 9. Infrastructure & -0.156 & 0.987 & -2.646 & 2.457 & $0.0285 *$ & $0.0750 *$ & $0.3911 *$ & $0.2061 *$ & $0.0206^{*}$ & $0.1887 *$ & $0.2748 *$ & $-0.1761^{*}$ & 1 & & 1.33 \\
\hline \multirow[t]{2}{*}{ 10. Distance } & 7.535 & 1.051 & 4.023 & 9.852 & $0.0277 *$ & $0.0068 *$ & $-0.0912 *$ & $-0.1145^{*}$ & $0.0466^{*}$ & $-0.0860 *$ & $-0.0670 *$ & $0.0399 *$ & $-0.1192 *$ & 1 & 1.04 \\
\hline & & & & & & & & & & & & & & Mean & 1.61 \\
\hline
\end{tabular}

Note: 2, 902, 716 observations (32, 685 firms) for all variables. *Pearson correlation significant at 0.01 level; ${ }^{1}$ Variance Inflation Factor (VIF) 
Table A8 Nested Logit estimation results (Base Model)

(1)

\begin{tabular}{lcc} 
VARIABLES & \multicolumn{2}{c}{$\begin{array}{c}\text { Base Model } \\
\text { Full sample }\end{array}$} \\
\hline Specialization & $0.575^{* * *}$ & $(0.0139)$ \\
Diversification & $0.389^{* * *}$ & $(0.0388)$ \\
Density & $0.162^{* * *}$ & $(0.0100)$ \\
R\&D & $0.022^{*}$ & $(0.0117)$ \\
Technology & $0.106^{* * *}$ & $(0.0160)$ \\
Market & $1.026^{* * *}$ & $(0.0210)$ \\
Wage & $-0.083^{* * *}$ & $(0.0204)$ \\
Labor & $0.088^{* *}$ & $(0.0210)$ \\
Infrastructure & $-0.062^{* * *}$ & $(0.0156)$ \\
Distance & $-0.944^{* * *}$ & $(0.0132)$
\end{tabular}

Country group $(c d)$ equation $^{1}$

Dissimilarity parameters

$\begin{array}{lcllll}\text { cd1_cons } & 1.466^{* * * *} & (0.1181) & \text { /cd1_tau } & 1.049 & (0.0853) \\ \text { cd2_cons } & 0.833^{* * * *} & (0.0850) & \text { /cd2_tau } & 1.015 & (0.0340) \\ \text { cd3_cons } & 5.419^{* * *} & (0.1099) & \text { /cd3_tau } & 0.496 & (0.0159) \\ \text { cd4_cons } & 1.748^{* * * *} & (0.3253) & \text { /cd4_tau } & 0.784 & (0.4478) \\ \text { cd5_cons } & 2.156^{* * * *} & (0.0898) & \text { /cd5_tau } & 0.859 & (0.0246) \\ \text { cd6_cons } & 0 & (\text { base) } & \text { /cd6_tau } & 1.128 & (0.0284) \\ \text { cd7_cons } & 1.289^{* * * *} & (0.0926) & \text { /cd7_tau } & 1.042 & (0.0419) \\ \text { cd8_cons } & 4.129 * * * & (0.1302) & \text { /cd8_tau } & 0.991 & (0.0598) \\ \text { cd9_cons } & 2.141^{* * *} & (0.0729) & \text { /cd9_tau } & 0.723 & (0.0176) \\ \text { cd10_cons } & 0.594 * * * & (0.0720) & \text { /cd10_tau } & 0.973 & (0.0268) \\ \text { cd11_cons } & 1.663 * * * & (0.0736) & \text { /cd11_tau } & 0.833 & (0.0191) \\ \text { cd12_cons } & 0.688^{* * * *} & (0.0700) & \text { /cd12_tau } & 0.745 & (0.0265)\end{array}$

LR test for IIA ( $\operatorname{tau}=1)$ :

Chi2(12) $\quad 827.73$

Prob>chi2 $\quad 0.0000$

\begin{tabular}{lc} 
Observations & $2,901,307$ \\
No. of cases & 32,681 \\
Log-likelihood & -128148.5 \\
Wald ch2(10) & 6240.69 \\
P-value chi2 & 0.00000 \\
\hline
\end{tabular}

Note: ${ }^{1}$ Host country groups (cd): cd1(AT), cd2(BE, NL, LU), cd3(RO, BG), cd4(CY, MT), cd5(CZ, SK, SI, HU, PL), cd6(DE), cd7(DK, SE, FI), cd8(EE, LT, LV), cd9(ES, PT, GR), cd10(FR), cd(11(IE, UK), cd12(IT)

Robust standard errors in parentheses

$* * * \mathrm{p}<0.001, * * \mathrm{p}<0.05, * \mathrm{p}<0.1$ 
Table A9 Mixed Logit estimation results (Base Model)

\begin{tabular}{|c|c|c|c|c|c|c|c|c|}
\hline VARIABLES & \multicolumn{2}{|c|}{$\begin{array}{c}\text { (1) } \\
\text { Full sample }\end{array}$} & \multicolumn{2}{|c|}{$\begin{array}{c}(2) \\
\text { EEMNE } \\
\text { sample }\end{array}$} & \multicolumn{2}{|c|}{$\begin{array}{c}(3) \\
\text { EU-EEMNE } \\
\text { sample } \\
\end{array}$} & \multicolumn{2}{|c|}{$\begin{array}{c}(4) \\
\begin{array}{c}\text { Non-EU-EEMNE } \\
\text { sample }\end{array} \\
\end{array}$} \\
\hline \multicolumn{9}{|l|}{ Mean } \\
\hline Specialisation & $0.733 * * *$ & $(0.0139)$ & $0.626 * * *$ & $(0.0351)$ & $0.438 * * *$ & $(0.0627)$ & $0.737 * * *$ & $(0.0473)$ \\
\hline Diversification & $0.087^{*}$ & $(0.0469)$ & $-0.569 * * *$ & $(0.1304)$ & $-1.083 * * *$ & $(0.269)$ & $-0.503 * *$ & $(0.1577)$ \\
\hline Density & $0.202 * * *$ & $(0.0108)$ & $0.395 * * *$ & $(0.0297)$ & $0.456 * * *$ & $(0.0560)$ & $0.351 * * *$ & $(0.0365)$ \\
\hline$R \& D$ & $0.127 * * *$ & $(0.0149)$ & $0.241 * * *$ & $(0.0363)$ & 0.0288 & $(0.0664)$ & $0.319 * * *$ & $(0.0447)$ \\
\hline Technology & $0.163 * * *$ & $(0.0181)$ & $0.389 * * *$ & $(0.0620)$ & $0.415 * * *$ & $(0.100)$ & $0.385 * * *$ & $(0.0699)$ \\
\hline Market & $1.118 * * *$ & $(0.0128)$ & $1.265^{* * *}$ & $(0.0377)$ & $1.255 * * *$ & $(0.0718)$ & $1.317 * * *$ & $(0.0466)$ \\
\hline Wage & $-0.170 * * *$ & $(0.0216)$ & $-0.339 * * *$ & $(0.0574)$ & $-0.496^{* * *}$ & $(0.0962)$ & $-0.228 * *$ & $(0.0751)$ \\
\hline Labor & $0.164 * *$ & $(0.0264)$ & $-0.147 * *$ & $(0.0703)$ & $0.285 * *$ & $(0.132)$ & $-0.246 * *$ & $(0.0866)$ \\
\hline Infrastructure & $-0.066 * * *$ & $(0.0156)$ & -0.061 & $(0.0456)$ & -0.101 & $(0.0770)$ & -0.033 & $(0.0583)$ \\
\hline Distance & $-0.983 * * *$ & $(0.0130)$ & $-2.218 * * *$ & $(0.0413)$ & $-1.964 * * *$ & $(0.0554)$ & $-2.355 * * *$ & $(0.0835)$ \\
\hline \multicolumn{9}{|c|}{ Host country dummies ${ }^{1}$} \\
\hline cd1 & $1.237 * * *$ & $(0.0537)$ & $0.238 * * *$ & $(0.1966)$ & $1.131^{* *}$ & $(0.348)$ & $0.876 * * *$ & $(0.2369)$ \\
\hline $\mathrm{cd} 2$ & $0.273 * * *$ & $(0.0259)$ & $0.791 * * *$ & $(0.0795)$ & $1.887 * * *$ & $(0.364)$ & $0.681 * * *$ & $(0.0927)$ \\
\hline $\mathrm{cd} 3$ & $4.483 * * *$ & $(0.0646)$ & $5.215^{* * *}$ & $(0.1819)$ & $5.925 * * *$ & $(0.363)$ & $5.031 * * *$ & $(0.2264)$ \\
\hline $\operatorname{cd} 4$ & $1.537 * * *$ & $(0.1770)$ & $1.088^{* *}$ & $(0.4233)$ & -14.63 & $(6,279)$ & 0.069 & $(0.4583)$ \\
\hline $\mathrm{cd} 5$ & $1.930 * * *$ & $(0.0518)$ & $2.579 * * *$ & $(0.1554)$ & $3.474 * * *$ & $(0.317)$ & $2.256 * * *$ & $(0.1908)$ \\
\hline $\operatorname{cd} 6$ & -0.056 & $(0.0369)$ & $0.477 * * *$ & $(0.1223)$ & $1.054 * * *$ & $(0.285)$ & $0.2989 * *$ & $(0.1364)$ \\
\hline $\mathrm{cd} 7$ & $1.043 * * *$ & $(0.0478)$ & $0.465^{*}$ & $(0.1761)$ & $1.207 * *$ & $(0.373)$ & $0.500 * *$ & $(0.1956)$ \\
\hline $\mathrm{cd} 8$ & $4.048 * * *$ & $(0.0700)$ & $5.494 * * *$ & $(0.1967)$ & $6.870 * * *$ & $(0.377)$ & $4.696 * * *$ & $(0.2540)$ \\
\hline $\operatorname{cd} 9$ & $1.284 * * *$ & $(0.0337)$ & $1.623 * * *$ & $(0.1196)$ & $2.639 * * *$ & $(0.269)$ & $1.183^{* * * *}$ & $(0.1387)$ \\
\hline $\operatorname{cd} 10$ & $0.215^{* * *}$ & $(0.0437)$ & $0.689 * * *$ & $(0.1474)$ & $1.091 * *$ & $(0.341)$ & $0.425 * *$ & $(0.1677)$ \\
\hline $\operatorname{cd} 11$ & $0.994 * * *$ & $(0.0441)$ & $2.169 * * *$ & $(0.1382)$ & $1.757 * * *$ & $(0.334)$ & $1.967 * * *$ & $(0.1595)$ \\
\hline \multicolumn{9}{|c|}{ Standard Deviations $^{2}$} \\
\hline Specialization & -0.132 & $(0.0973)$ & 0.073 & $(0.2662)$ & 0.131 & $(0.366)$ & -0.224 & $(0.2116)$ \\
\hline Diversification & $1.180 * * *$ & $(0.0920)$ & $1.699 * * *$ & $(0.2192)$ & $-2.815^{* * *}$ & $(0.307)$ & $1.909 * * *$ & $(0.2571)$ \\
\hline Density & $0.145^{* * *}$ & $(0.0269)$ & 0.001 & $(0.0392)$ & 0.0438 & $(0.152)$ & 0.006 & $(0.0709)$ \\
\hline$R \& D$ & 0.001 & $(0.0310)$ & -0.005 & $(0.0612)$ & -0.0264 & $(0.152)$ & -0.011 & $(0.0799)$ \\
\hline Technology & 0.020 & $(0.0769)$ & 0.211 & $(0.3621)$ & $0.589 * *$ & $(0.235)$ & -0.236 & $(0.3076)$ \\
\hline Market & 0.00007 & $(0.0180)$ & -0.001 & $(0.0316)$ & -0.0005 & $(0.0674)$ & 0.004 & $(0.0515)$ \\
\hline Wage & -0.009 & $(0.0226)$ & -0.006 & $(0.0411)$ & -0.0077 & $(0.168)$ & 0.006 & $(0.0562)$ \\
\hline Labor & $0.951 * * *$ & $(0.0415)$ & $0.745 * * *$ & $(0.1526)$ & $0.745 * *$ & $(0.304)$ & $0.854 * * *$ & $(0.1484)$ \\
\hline Infrastructure & -0.314 & $(0.0394)$ & 0.003 & $(0.0357)$ & -0.0028 & $(0.102)$ & 0.001 & $(0.0585)$ \\
\hline Distance & $0.392 * * *$ & $(0.0407)$ & 0.010 & $(0.0620)$ & -0.0139 & $(0.0920)$ & -0.085 & $(0.1395)$ \\
\hline Observations & $2,901,307$ & & 420,871 & & 147,352 & & 275,569 & \\
\hline Log-likelihood & -128446.7 & & 15669.8 & & -4806 & & 10622.9 & \\
\hline LR $\operatorname{chi} 2(10)$ & 231.45 & & 21.81 & & 32.91 & & 24.83 & \\
\hline P-value Chi & 0.0000 & & 0.0161 & & 0.0003 & & 0.005 & \\
\hline
\end{tabular}

Note: ${ }^{1}$ Host country groups (cd): cd1(AT), cd2(BE, NL, LU), cd3(RO, BG), cd4(CY, MT), cd5(CZ, SK, SI, HU, PL), cd6(DE), cd7(DK, SE, FI), cd8(EE, LT, LV), cd9(ES, PT, GR), cd10(FR), cd(11(IE, UK), cd12(IT)

${ }^{2}$ The sign of the estimated standard deviations is irrelevant: interpret them as being positive.

Robust standard errors in parentheses

$* * * \mathrm{p}<0.001, * * \mathrm{p}<0.05,{ }^{*} \mathrm{p}<0.1$ 
Table A10 CLM regression results with controls (sector, entry mode, experience)

\begin{tabular}{|c|c|c|c|c|c|c|c|c|}
\hline \multirow{2}{*}{$\begin{array}{l}\text { VARIABLES } \\
\text { Specialization }\end{array}$} & \multicolumn{2}{|c|}{ (1) Base Model } & \multicolumn{4}{|c|}{$\begin{array}{c}\text { Interaction models }^{1} \\
\text { (3) EU-EEMNE }\end{array}$} & \multicolumn{2}{|c|}{ (4) Non-EU-EEMNE } \\
\hline & $0.642 * * *$ & $(0.0305)$ & $0.634 * * *$ & $(0.0315)$ & $0.614 * * *$ & $(0.0322)$ & $0.634 * * *$ & $(0.0322)$ \\
\hline Diversification & $0.431 * * *$ & $(0.0728)$ & $0.478 * * *$ & $(0.0750)$ & $0.469 * * *$ & $(0.0760)$ & $0.472 * * *$ & $(0.0759)$ \\
\hline Density & $0.205 * * *$ & $(0.0137)$ & $0.175^{* * *}$ & $(0.0141)$ & $0.187 * * *$ & $(0.0144)$ & $0.164 * * *$ & $(0.0143)$ \\
\hline R\&D & $0.295 * * *$ & $(0.0211)$ & $0.298 * * *$ & $(0.0219)$ & $0.301 * * *$ & $(0.0224)$ & $0.302 * * *$ & $(0.0221)$ \\
\hline Technology & $0.397 * * *$ & $(0.0316)$ & $0.365 * * *$ & $(0.0330)$ & $0.351 * * *$ & $(0.0334)$ & $0.380 * * *$ & $(0.0334)$ \\
\hline Market & $1.045 * * *$ & $(0.0174)$ & $1.048 * * *$ & $(0.0180)$ & $1.039 * * *$ & $(0.0183)$ & $1.045 * * *$ & $(0.0182)$ \\
\hline Wage & $-0.341 * * *$ & $(0.0299)$ & $-0.297 * * *$ & $(0.0305)$ & $-0.298 * * *$ & $(0.0314)$ & $-0.311 * * *$ & $(0.0312)$ \\
\hline Labor & $0.327 * * *$ & $(0.0426)$ & $0.385 * * *$ & $(0.0440)$ & $0.362 * * *$ & $(0.0451)$ & $0.406^{* * *}$ & $(0.0446)$ \\
\hline Infrastructure & $-0.068 * * *$ & $(0.0185)$ & $-0.0936^{* * *}$ & $(0.0189)$ & $-0.075 * * *$ & $(0.0194)$ & $-0.079 * * *$ & $(0.0193)$ \\
\hline Distance & $-0.856^{* * *}$ & $(0.0202)$ & $-0.802 * * *$ & $(0.0209)$ & $-0.792 * * *$ & $(0.0212)$ & $-0.802 * * *$ & $(0.0215)$ \\
\hline \multicolumn{9}{|c|}{ Interaction terms - country of origin $^{1}$} \\
\hline Specialization & - & - & -0.0164 & $(0.0523)$ & $-0.150^{*}$ & $(0.0910)$ & 0.0448 & $(0.0633)$ \\
\hline Diversification & - & - & $-0.582 * * *$ & $(0.154)$ & $-0.888 * * *$ & $(0.247)$ & $-0.511 * *$ & $(0.196)$ \\
\hline Density & - & - & $0.299 * * *$ & $(0.0298)$ & $0.222 * * *$ & $(0.0544)$ & $0.313 * * *$ & $(0.0358)$ \\
\hline$R \& D$ & - & - & $0.0886 * *$ & $(0.0445)$ & -0.0351 & $(0.0726)$ & 0.0697 & $(0.0556)$ \\
\hline Technology & - & - & $0.175 * *$ & $(0.0714)$ & $0.231^{*}$ & $(0.134)$ & 0.127 & $(0.0816)$ \\
\hline Market & - & - & -0.0162 & $(0.0375)$ & $-0.179 * *$ & $(0.0767)$ & 0.0601 & $(0.0427)$ \\
\hline Wage & - & - & $-0.271 * * *$ & $(0.0492)$ & $-0.508 * * *$ & $(0.0885)$ & 0.0043 & $(0.0626)$ \\
\hline Labour & - & - & $-0.717 * * *$ & $(0.0817)$ & 0.124 & $(0.152)$ & $-0.996 * * *$ & $(0.0994)$ \\
\hline Infrastructure & - & - & $0.272 * * *$ & $(0.0290)$ & $0.313 * * *$ & $(0.0545)$ & $0.204 * * *$ & $(0.0346)$ \\
\hline Distance & - & - & $-1.146^{* * * *}$ & $(0.0542)$ & $-0.914 * * *$ & $(0.0656)$ & $-0.737 * * *$ & $(0.154)$ \\
\hline $\begin{array}{l}\text { Interaction terms } \\
{\text { - } \text { sector }^{2}}^{2}\end{array}$ & \multicolumn{2}{|c|}{ included } & \multicolumn{2}{|c|}{ included } & \multicolumn{2}{|c|}{ included } & \multicolumn{2}{|c|}{ included } \\
\hline $\begin{array}{l}\text { Interaction terms } \\
- \text { mode of entry }\end{array}$ & \multicolumn{2}{|c|}{ included } & \multicolumn{2}{|c|}{ included } & \multicolumn{2}{|c|}{ included } & \multicolumn{2}{|c|}{ included } \\
\hline $\begin{array}{l}\frac{\text { Interaction terms }}{\text {-experience }^{4}} \\
\text { expen }^{2}\end{array}$ & \multicolumn{2}{|c|}{ included } & \multicolumn{2}{|c|}{ included } & \multicolumn{2}{|c|}{ included } & \multicolumn{2}{|c|}{ included } \\
\hline$\frac{\text { Host country }}{\text { group dummies }}{ }^{5}$ & \multicolumn{2}{|c|}{ included } & \multicolumn{2}{|c|}{ included } & \multicolumn{2}{|c|}{ included } & \multicolumn{2}{|c|}{ included } \\
\hline Observations & $2,185,828$ & & $2,185,828$ & & $2,035,354$ & & $2,113,903$ & \\
\hline Log-likelihood & $-96,620$ & & $-96,231$ & & $-90,002$ & & $-93,404$ & \\
\hline Chi-square & 23,750 & & 24,607 & & 22,565 & & 23,364 & \\
\hline P-value Chi & 0.0000 & & 0.0000 & & 0.0000 & & 0.0000 & \\
\hline PseudoR2 & 0.123 & & 0.127 & & 0.125 & & 0.124 & \\
\hline
\end{tabular}

Note: ${ }^{1}$ Interaction of variables with dummy for investors from all emerging markets (specification (2)), from European emerging markets (specification (3)), and non-EU emerging market (specification (4)) (see Annex Tables A1 for country lists)

${ }^{2}$ Interaction with sector dummy (1= manufacturing: NACE Rev. 1 10-33, 0= services NACE Rev. 1 35-98)

${ }^{3}$ Interaction with mode of entry dummy ( $1=$ M\&As, $0=$ greenfield $)$

${ }^{4}$ Interaction with host country experience dummy (1= investor had other foreign affiliates prior to entry)

${ }^{5}$ Host country groups: cd1(AT), cd2(BE, NL, LU), cd3(RO, BG), cd4(CY, MT), cd5(CZ, SK, SI, HU, PL), cd6(DE), cd7(DK, SE, FI), cd8(EE, LT, LV), cd9(ES, PT, GR), cd10(FR), cd(11(IE, UK), cd12(IT) (reference group).

Robust standard errors in parentheses

$* * * \mathrm{p}<0.001, * * \mathrm{p}<0.05, * \mathrm{p}<0.1$ 